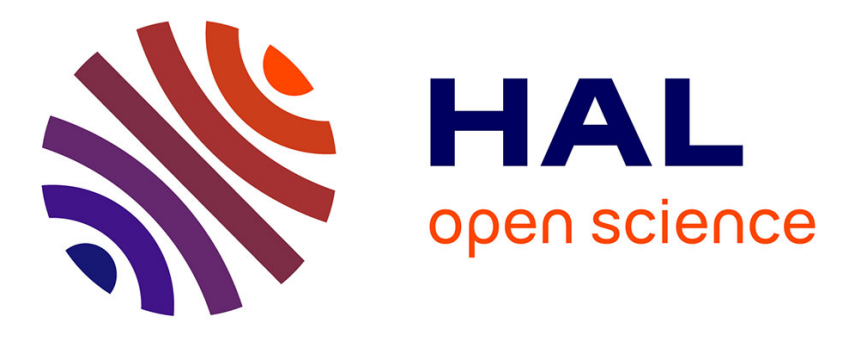

\title{
Quantile-based individual risk measures for rockfall-prone areas
}

Manon Farvacque, Nicolas Eckert, Franck Bourrier, Christophe Corona, Jérôme Lopez-Saez, David Toe

\section{To cite this version:}

Manon Farvacque, Nicolas Eckert, Franck Bourrier, Christophe Corona, Jérôme Lopez-Saez, et al.. Quantile-based individual risk measures for rockfall-prone areas. International Journal of Disaster Risk Reduction, 2021, 53, pp.101932. 10.1016/j.ijdrr.2020.101932 · hal-03129211

\section{HAL Id: hal-03129211 https://hal.science/hal-03129211}

Submitted on 14 Sep 2021

HAL is a multi-disciplinary open access archive for the deposit and dissemination of scientific research documents, whether they are published or not. The documents may come from teaching and research institutions in France or abroad, or from public or private research centers.
L'archive ouverte pluridisciplinaire HAL, est destinée au dépôt et à la diffusion de documents scientifiques de niveau recherche, publiés ou non, émanant des établissements d'enseignement et de recherche français ou étrangers, des laboratoires publics ou privés.

\section{(c)(1)}

Distributed under a Creative Commons Attribution| 4.0 International License 


\title{
Quantile-based individual risk measures for rockfall-prone areas
}

\author{
Manon Farvacque ${ }^{a, *}$, Nicolas Eckert ${ }^{\mathrm{a}}$, Franck Bourrier ${ }^{\mathrm{a}}$, Christophe Corona ${ }^{\mathrm{b}}$, \\ Jérôme Lopez-Saez ${ }^{\mathrm{c}}$, David Toe ${ }^{\mathrm{d}}$ \\ ${ }^{\text {a }}$ Université Grenoble Alpes, INRAE, UR ETNA - 2 rue de la papeterie, St-Martin-d'Hères, 38402, France \\ ${ }^{\mathrm{b}}$ Université de Clermont Auvergne, CNRS, GEOLAB UMR - 4 rue Ledru, Clermont-Ferrand, 63057, France \\ ${ }^{\mathrm{c}}$ Climate Change Impacts and Risks in the Anthropocene C-CIA, Institute for Environmental Sciences, University of Geneva - Bd. Carl-Vogt 66, Geneva, 1205, \\ Switzerland \\ ${ }^{\mathrm{d}}$ Université Grenoble Alpes, INRAE, UR LESSEM - 2 rue de la papeterie, St-Martin-d'Hères, 38402, France
}

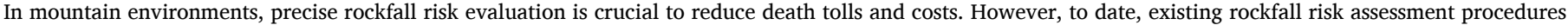

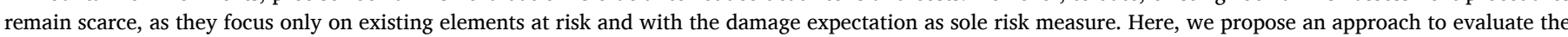

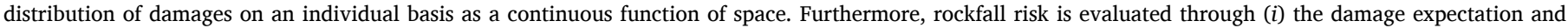

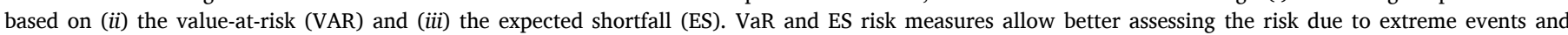

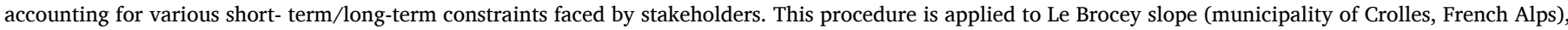

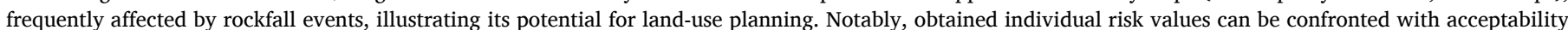

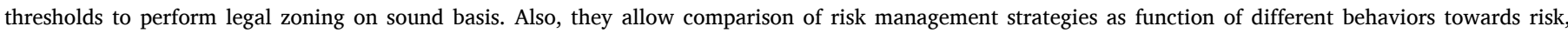

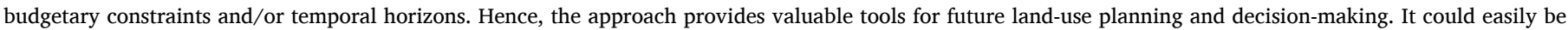
transferred to other hazards as a wider contribution to the determination of the best balance between safety and sustainability.
\end{abstract}

\section{Introduction}

In mountain areas, rapid landslides result from the combination of topographic, lithologic and climatic factors. Seeing them as random processes defines the concept of mountain hazards, and additional consideration of their damageable consequences for various stakes identifies mountain risks. This is a constant threat for settlements and their inhabitants and creates conflict between development and safety. No countermeasures can be taken after mass movement initiation because the time before the damageable impact is generally less than 1 min. Risk mitigation through rigorous land-use planning and/or design of defense structures is therefore a crucial issue for authorities and stakeholders so as to reduce death tolls, especially in densely populated valleys where space is limited and real estate pressure is continuously increasing [56,58,64].

Rockfalls are a common type of fast moving landslide [46], corresponding to the detachment of individual rocks and boulders of different sizes from a vertical or sub-vertical cliff and to their travel down the slope by free falling, bouncing and/or rolling [30,65]. Rockfalls are triggered by multiple factors such as short-term weather conditions (freeze-thaw events, temperature variations or intense precipitation), seismic activity, permafrost degradation, vegetation (root wedging) or anthropogenic activities [18,55]. This phenomenon represents a major hazard in mountain areas worldwide, endangering human lives, transportation infrastructures, industry and dwellings [2,40,42]. Abundant literature reports fatalities, e.g., in Switzerland [6,62], France [4], Italy [1], Austria [44] or Canada [10].

In that respect, quantitative risk assessment (QRA) procedures initially developed for other landslide types [16,38,39,47] have been adapted to the specificities of rockfall processes, increasing the awareness of existing risk levels and the appreciation of the efficiency of the actions undertaken $[1,13,15,16]$. In QRAs, rockfall risk for exposed elements is estimated by including in the analysis each component of risk: the hazard, the exposure and the vulnerability. However, in practice, this quantitative estimation is challenging [13,32,53], so that state-of-the-art methods remain scarce $[1,14,43,45]$. Notably, risk is

\footnotetext{
* Corresponding author.

E-mail address: manon.farvacque@inrae.fr (M. Farvacque).
} 
always evaluated for already existing buildings and infrastructures only $[1,13,54,61]$. Mathematically consistent approaches for evaluating individual risk as a continuous function of space in areas potentially suitable for establishing new stakes (e.g. new building constructions) are therefore lacking. This precludes (i) reliable anticipation of future rockfall risk in a context of urban plans evolving rapidly and substantially evolving [31], and (ii) zoning on the basis of acceptability thresholds $[3,25,43,66]$.

Furthermore, risk remains in the field of rockfalls - as for most of natural hazards - always defined as the damage expectation $[1,26,27,35$, 36]. This risk measure has been classically adopted since it is intuitive and easy to compute. Indeed, given its linearity, the expectation of a sum of random variables is equal to the sum of individual expectations, and this holds if they are independent or not. From this perspective, risk is thus additive, allowing to evaluate easily the risk for a whole system by summing individual risks for each element of the system [32]. However, the damage expectation as a measure of risk is also hampered by several limitations. First, the damage expectation fails to capture the whole range of consequences especially those related to rare events [68]. It therefore tends to underestimate the consequences of low-frequency/high-magnitude events. Besides, putting forward the damage expectation as sole measure of risk does not offer any alternative integrating short/long term constraints or trade-offs between protection and costs faced by decision-makers. Specifically, this risk measure does not consider the time necessary to reach the expected damage, and the maximal damage that may be expected during this time [28].

Quantifying risks is an old question in statistics, economics and finance. While variance and standard deviation were historically the dominating risk measures in financial markets, measures based on quantiles have became popular in actuarial sciences since the 1990 [29, 41]. One of the most widely metric used in banking and other financial institutions is the value-at-risk (VaR). For example, this measure has been successfully adopted by the Basel Committee on Banking Supervision for the prudential regulation of banks and owes its popularity to its conceptual simplicity. Value-at-risk indicates the damage which is not exceeded for a portfolio, with a given probability $\alpha$, over a predetermined horizon [51]. Unfortunately, VaR fails to capture the extent of consequences beyond the confidence level $\alpha$. In view of this limitation, risk managers often prefer in practice the expected shortfall (ES), sometimes called conditional value-at-risk (CVaR), average value-at-risk (AVaR) or expected tail (ETL). ES measures the expected damage that is incurred in the events that are worse than the VaR of the portfolio [51]. It thus provides a better evaluation of damages to a portfolio due to unexpected or extreme scenarios.

In this context, we develop here an approach for evaluating new individual quantile-based rockfall risk measures relying on the entire distribution of damages evaluated as a continuous function of space in an area where new constructions are envisaged. We apply it to evaluate risk at each $10 \times 10 \mathrm{~m}^{2}$ cell of Le Brocey slope (Crolles municipality, French Alps), where numerous rockfalls and intense urban sprawl dynamic have been reported since the beginning of the 20th century [48]. The complete distribution of damages is obtained by combining rockfall simulations with the physical vulnerability of potentially affected buildings and the complete distribution of block volumes in the range $1-20 \mathrm{~m}^{3}$. At each cell, rockfall risk is evaluated as (1) the expected damage, (2) the value-at-risk, and (3) the expected shortfall risk measures. What follows details our innovative methodological approach and illustrates with the case study the added value of the resulting panel of risk maps for land-use planning.

\section{Methods}

\subsection{Risk measures}

\subsubsection{Risk as annual expected damage}

In the field of natural hazards, risk is generally defined as the com- bination of hazards with its consequences (e.g. Ref. [5,24,59,60]). This provides a statistical value for the expected damage per year [17,64]:

$\bar{R}_{z}=q(z) \times Z \times \lambda \times \mathbb{E}\left[D_{z}\right]$.

$\bar{R}_{z}$ represents the expectations of the consequences (or a certain amount of damage) of hazard for the element at risk $z$, characterized by an exposure factor $q(z)$ and a value $Z$. In the most common configurations, these elements are physical (i.e. people, traffic infrastructure, buildings), but other less tangible aspects can be introduced such as the image and aesthetics of an element. $\lambda$ is the temporal occurrence frequency of potentially damageable events (in events/yr). $D_{z}$ is the random variable describing the damage distribution for the element $z$ which is at risk. Hence, $\mathbb{E}\left[D_{z}\right]=\int d_{z} \mathscr{L}\left(d_{z}\right) \mathrm{d} d_{z}$ with $\mathscr{L}\left(d_{z}\right)$ the probability distribution of damages for the element $z$.

For rockfall risk, this generic equation is often written as:

$\bar{R}_{z}=q(z) \times Z \times \lambda \times p_{z} \int p_{z}($ Event $) d_{z}($ Event $) \mathrm{d}$ Event.

Integration is therefore performed over the variability of rockfall events. The latter is related to different physical and kinetic properties, i. e. volume, mass, shape, translational and rotational energies, passing height, impact angle, etc. from one rockfall to another. In addition, the damage expectation is evaluated considering only rockfall events that reach the element $z$. Hence, $p_{z}$ is the reach probability on the element at risk $z, p_{z}$ (Event) the local distribution of physical and kinetic properties of rockfall events reaching $z$ and $d_{z}$ (Event) the resulting damage. Depending on the purpose of the analysis, the damage can refer, e.g., to a failure probability for buildings and infrastructures (physical vulnerability) or to lethality rates (vulnerability of people). Based on vulnerability curves $[11,16,33,34]$, it is expressed on a scale ranging from 0 (no damage) to 1 (total damage).

Eventually, due to the complexity and suddenness of rockfall processes, several parameters (e.g. fragmentation of the block, impact angle, etc.) that would be useful for risk assessment are systematically lacking [9]. As a consequence, in practice, kinetic energy is generally the sole magnitude variable considered. This leads the following simplified equation:

$\bar{R}_{z}=q(z) \times Z \times \lambda \times p_{z} \int p_{z}(E) d_{z}(E) \mathrm{d} E$,

where $p_{z}(E)$ is the local distribution of kinetic energy $E$ conditional to reach and $d_{z}(E)$ the resulting damage.

\subsubsection{Quantile-based risk measures}

To extent the risk analysis to alternative risk metrics, such as quantile-based measures, rather than its sole expectation, the complete distribution of damages $\mathscr{L}(d)$ is required (the indexing by $z$ is relaxed for simplicity). In that respect, we developed in this study a methodology that evaluates it all over the rockfall volume distribution as:

$\mathscr{L}(d)=\int_{v_{C l}} \mathscr{L}\left(d, v_{C l}\right) \mathrm{d} v_{C l}=\int_{v_{C l}} \mathscr{L}\left(d \mid v_{C l}\right) p\left(v_{C l}\right) \mathrm{d} v_{C l}$,

where $v_{C l}$ denotes the rockfall volume class and $p\left(v_{C l}\right)$ the related probability distribution.

Specifically, we consider here the value-at-risk (VaR) and the expected-shortfall (ES) risk measures. Value-at-risk and expected shortfall are quantile-based measures that hedge against worst-case damages defined beyond a confidence level $\alpha$. In grater details, the value-at-risk at level $\alpha \in(0,1)$ of a variable $D$ is given by the smallest damage $d$ such that the probability that the damage $D$ exceeds $d$ is not larger than $(1-\alpha)$. In other words, VaR is simply defined as the $\alpha$-quantile of the damage distribution $\mathscr{L}(d)$. Formally:

$\mathrm{VaR}_{\alpha}=\inf \{d \in \mathbb{R} \mid \operatorname{Pr}\{D \geq d\} \leq(1-\alpha)\}=\inf \{d \in \mathbb{R} \mid \mathscr{L}(d) \geq \alpha\}$, 
where $\operatorname{Pr}\{D \geq d\}$ is the probability that the damage $D$ exceeds $d$ and $\mathscr{L}(d)$ the cumulative distribution function of damage, both conditional to rockfall volume distribution.

Similarly, the expected shortfall at level $\alpha \in(0,1)$ is defined as the expected coverage in the (1- $\alpha$ ) worst-case damages. Hence, it is closely related to value-at-risk as it corresponds to the expected damage that is incurred in the events exceeding VaR. Here we get:

$\mathrm{ES}_{\alpha}=\mathbb{E}\left(D \mid D \geq \mathrm{VaR}_{\alpha}\right)$.

By definition, value-at-risk and expected shortfall are risk measures which depend only on the damage distribution $\mathscr{L}(d)$ and on the confidence level $\alpha$. For $\alpha$ set at $0, \mathrm{ES}_{\alpha}$ is equal to the expected damage of the distribution. Similarly, if $\mathscr{L}(d)$ follows a normal distribution and $\alpha=$ 0.5, $\mathrm{VaR}_{\alpha}$ corresponds to $\mathbb{E}(D)$. Obviously, $\mathrm{VaR}_{\alpha} \leq \mathrm{ES}_{\alpha}$ (Fig. 1 [51]).

No clear-cut recommendation can be given on the choice of $\alpha$ since the latter is a user-defined parameter that reflects the risk attitudes of the decision-maker [69]. Here, value-at-risk and expected shortfall are evaluated for different temporal horizons $t$ (in years). Hence, $t$ gives the length of the risk-management horizon for the stakeholder and is associated to a certain confidence level given by:

$\alpha=1-\frac{1}{\lambda t}$,

where $\lambda$ corresponds to the temporal occurrence frequency of rockfall events. Demonstration of this mathematical relation is proposed in Appendix A.

\subsection{The different components of rockfall risk assessment}

Rockfall risk assessment involves three main steps: (1) analysis of rockfall activity in order to quantify the temporal occurrence of events and their associated volume distribution; (2) modeling of rockfall trajectories to account for the spatially distributed nature of the rockfall process; (3) evaluating damages suffered by elements at risk due to rockfall impacts by making use of so-called vulnerability curves. Eventually, the required risk estimates are derived from the resulting damage distribution.

\subsubsection{Rockfall initiation}

Potential rockfall release areas are deduced from a DEM-based geomorphometric approach known as the slope angle frequency distribution (SAFD) procedure $[49,52]$. In this procedure, using the Excel-based Histofit application, slope angle distribution is decomposed in several
Gaussian distributions. The terrain is considered a potential rockfall source if its slope angle exceeds a certain threshold, which in turn is defined where the Gaussian distribution corresponding to the "rock cliff' morphological unit becomes dominant over the one corresponding to the "steep slope" unit.

Furthermore, we separately investigated (i) the temporal occurrence of rockfall events and (ii) their associated volume distribution through a catalog of past events. Assuming that any rockfall is characterized by the detachment of an individual block that will not disintegrate along the path, the distribution of volumes exceeding a volume threshold value $u$ is characterized by an asymptotic model of the generalised Pareto distribution (GPD) family [12]. According to Pickands (1975) [57], for any random variable, this is the true limiting distribution as soon as $u$ is high enough. The rockfall volume distribution is therefore given by:

$\operatorname{Pr}\{V>v \mid V>u\}=\left[1+\xi\left(\frac{v-u}{\sigma}\right)\right]^{-1 / \xi}$,

where $V$ represents the volume of the blocks (in $\mathrm{m}^{3}$ ) and $u, \sigma$ and $\xi$, the location, scale and shape of the GPD distribution, respectively.

\subsubsection{Rockfall propagation}

Rockfall propagation is supported by a high-resolution 3D numerical modeling performed using the Rockyfor3D (v5.0) code [19]. On the basis of a digital elevation model, this probabilistic process-based rockfall trajectory model combines physically based deterministic algorithms with stochastic approaches to simulate rockfall in three dimensions. The model calculates sequences of classical, uniformly accelerated parabolic free fall through the air and rebounds on the slope surface and trees (for details see Dorren et al., 2005 [20]). During each rebound, the model allows the block to deviate from its direction before rebounding. If an impact against a tree takes place, part of the rock energy is dissipated as a function of the stem diameter of the corresponding tree and the relative position between the rock and tree center. As outputs, the model provides, for example, information on rock propagation for any location in the study site, the number of rocks passing through a given surface or the kinetic energy values of all simulated blocks at a given location.

\subsubsection{Rockfall damage}

By considering a potential area theoretically available for urban development, this study aims at assessing rockfall risk for a potential structural element (building type). Hence, the energies recorded over the Rockyfor3D simulations are expressed in terms of damage value on a
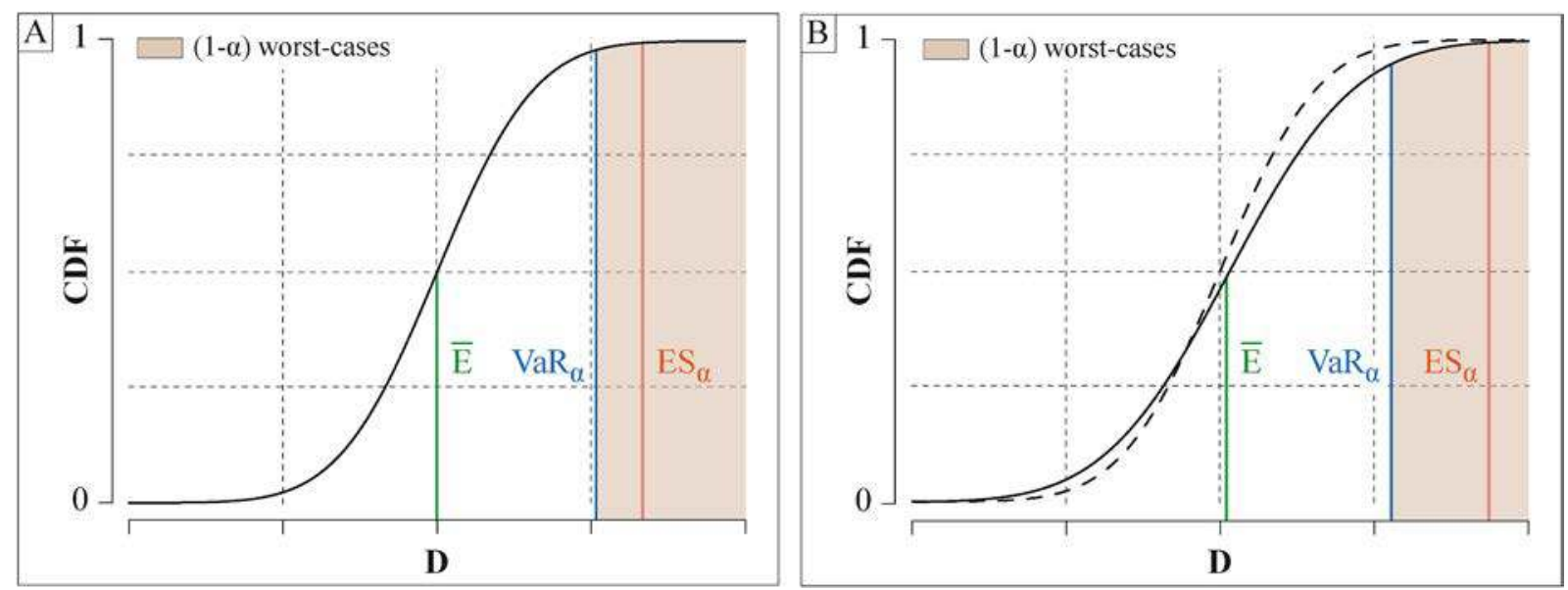

Fig. 1. Simplified representation of the value-at-risk (VaR) and expected shortfall (ES) for a normal (A) and a heavy-tailed (B) cumulative distribution function of the random variable D expressing the damage for the considered element at risk. These quantile-based measures are compared with the expected damage ( $\overline{\mathrm{E}})$. From the normal to the heavy-tailed distribution, minor variations are observed for the expected damage and the value-at-risk, while the expected shortfall substantially increases. 
theoretical structure based on the physical vulnerability curve proposed by Agliardi et al. (2009) [1]. This curve results from the back analysis of the 2004 rockfall event in Fiumelatte (Italy) and converts the energy of the impact into potential damage varying between 0 (no structural damage) and 1 (total collapse). It is expressed as:

$d(E)=1-\frac{1.358}{1+e^{\frac{E-129000}{120300}}}$,

where $d$ represents the damage on a structure and $E$ the impact energy (in Joules).

\section{Application}

\subsection{Case study}

As a typical case-study, our approach was applied on Le Brocey slope, located in the Crolles municipality (northeast of the Grenoble conurbation), in the Isère department (Fig. 2A, B, C). The study site forms a 700-m long talus slope settled on the eastern slope of the Chartreuse Massif (French Alps). Its elevation ranges between 420 and $260 \mathrm{~m}$ a.s.l., from the lower limit of a centennial protection forest to the road D1090. Its slope angles decrease gradually from $20^{\circ} \pm 05^{\circ}$ in the upper portion to $04^{\circ} \pm 03^{\circ}$ at the level of the current urban front (Fig. 2D and E). Landuse and land-cover patterns are characterized by a mosaic of wasteland, grassland, wooded and constructed plots $[32,48]$. The site is topped by a 300-m-high sub-vertical cliff made of thickbedded limestones and marls from the upper Jurassic period [23]. The cliff triggers rockfall with sizes varying from gravel clasts to blocks with volumes $>30 \mathrm{~m}^{3}$. Historical archives, fresh blocks, recent impact craters on the ground and visible growth disturbances (i.e., scars, decapitated trees) on the forest stand confirm ongoing strenuous rockfall activity on the slopes.

\subsection{Rockfall probability}

According to the Histofit routine, the threshold slope angle for source areas was set at $49^{\circ}$ [31]. Terrain units exceeding the threshold slope angle were mapped into a Geographical Information System (GIS) and converted to raster for subsequent trajectographic analyses. In that respect, 6371 cells were identified as potential rockfall sources, corresponding to a total surface of $35.9 \mathrm{hm}^{2}$.

In addition to susceptibility, the temporal probability of failure must be addressed to define the probability of the occurrence of a rockfall event [40]. For this purpose, 29 blocks potentially released from a $11.5-\mathrm{hm}^{2}$ cliff section were inventoried along a 900-m-long transect [32]. Given the relative freshness of the blocks (limited patina, absence of blunt or rounded-off edges, lichens or vegetation on the surface) and the presence of visible scars on tree stems, we estimated that the observation period of rockfall events should not reasonably exceed one century. In addition, the temporal occurrence was defined for volumes greater than the threshold $u=1 \mathrm{~m}^{3}$ as we consider it as the minimum volume that can significantly damage infrastructures. Assuming that rockfall stating points are homogeneously distributed on the rocky cliff, the rockfall frequency was thus estimated at 0.015 events $/ \mathrm{yr} / \mathrm{hm}^{2}$ [32]. Consequently, the total frequency $\lambda$ of rockfall events equal 0.53 events/yr.

Finally, the probability distribution of rockfall volumes was obtained by fitting the GPD distribution using the maximum likelihood procedure on inventoried rockfall events [12]. Hence, a reduced catalog containing only the volumes $u$ and greater was retained. This resulted in maximum likelihood estimators $\sigma$ and $\xi$ equal to 0.94 and 0.355 , respectively (Fig. 3B). The related uncertainty was obtained by propagating their asymptotic covariance matrix using a delta-like approach [12].
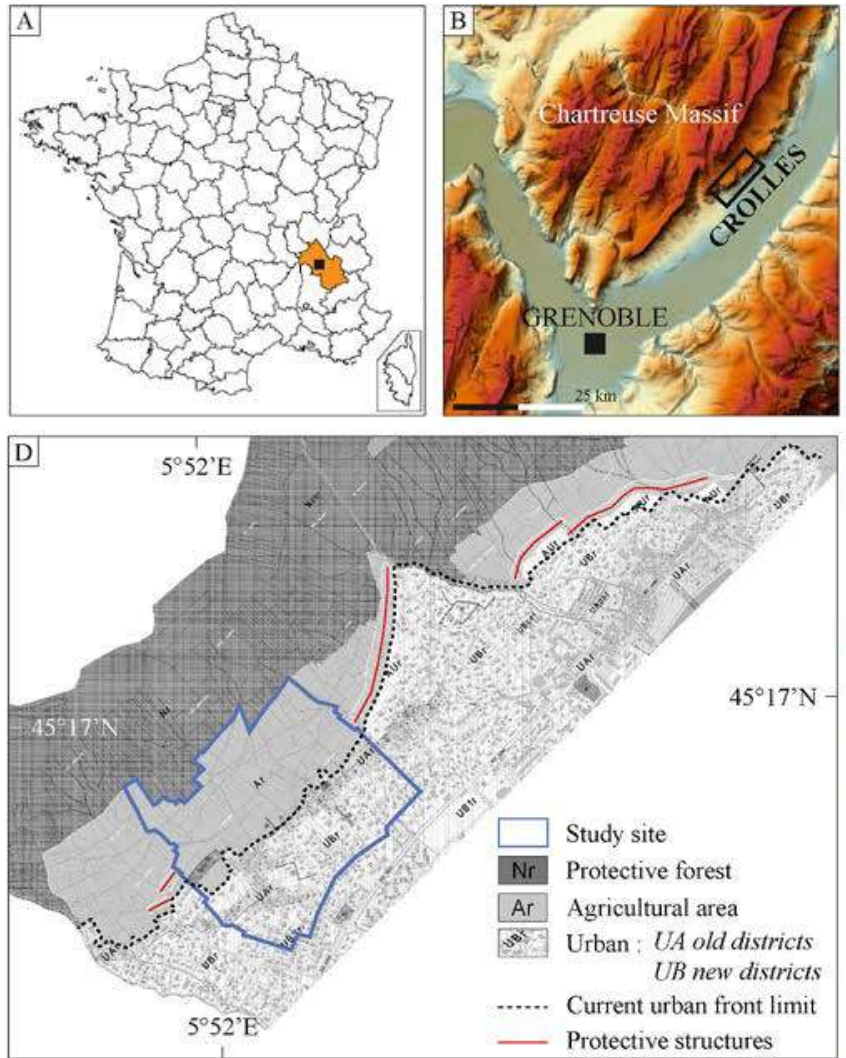
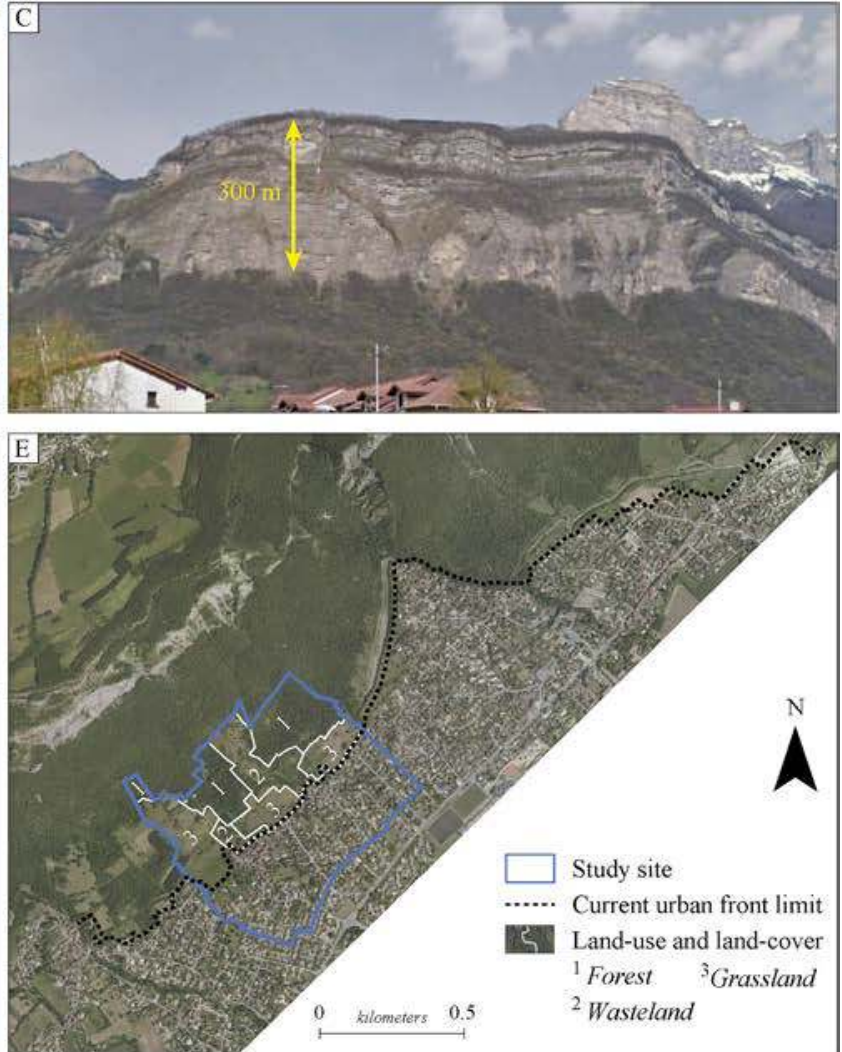

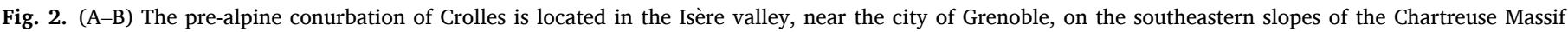

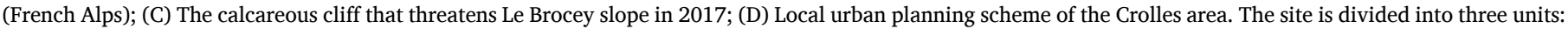
the protection forest, the agricultural area, and the urbanized area; (E) Land-use and land-cover (LULC) map of Le Brocey slopes in 2017. 

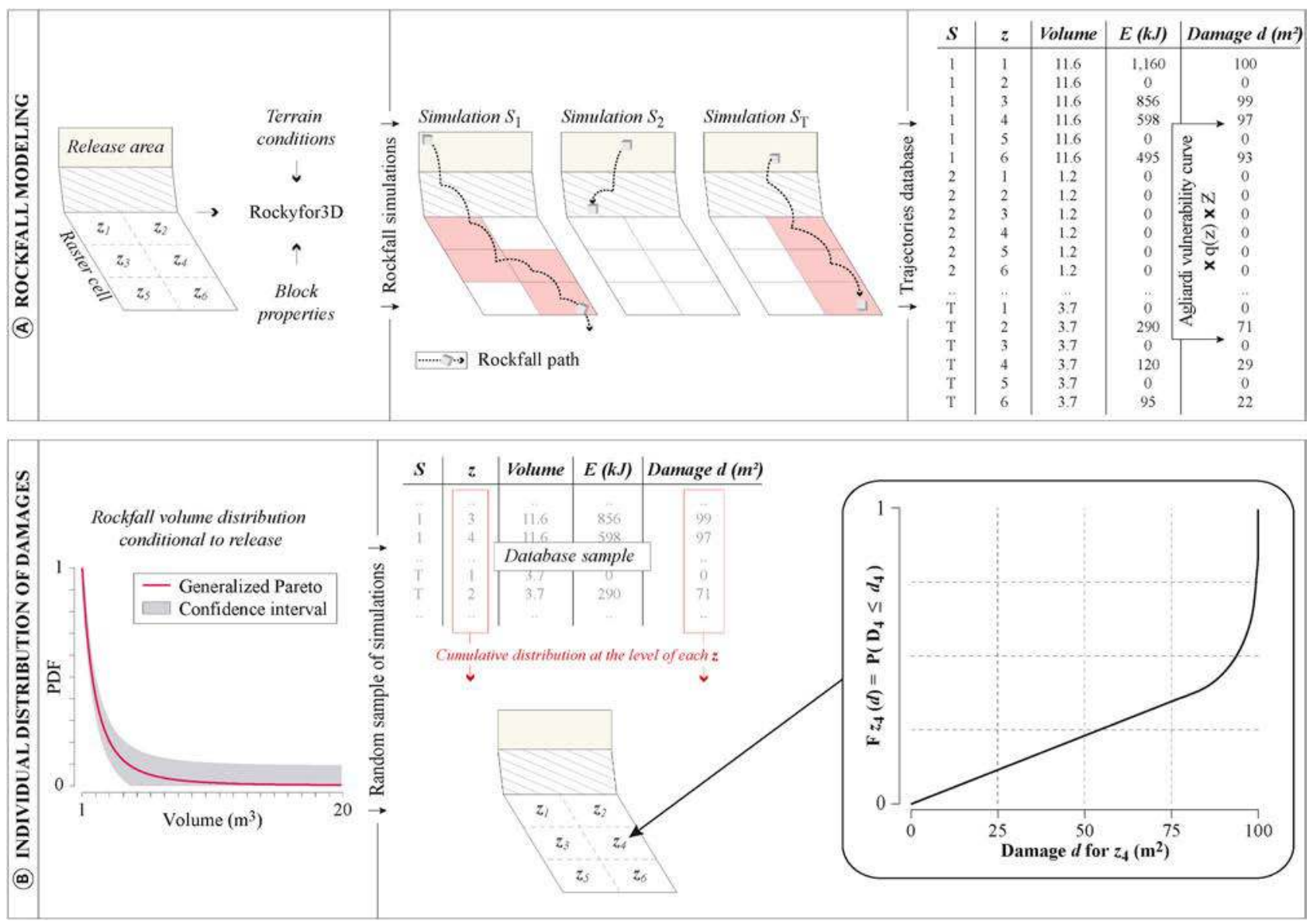

Fig. 3. General scheme of the framework used to quantify the distribution of individual damages due to rockfall for rock volumes in the range $1-20 \mathrm{~m}^{3}$. The methodology is summarized in two main steps: (A) Rockfall propagation with the Rockyfor3D code and data storage (simulation and cell IDs, volumes, energies and probabilities of damage). (B) Estimation of individual damage cumulative probability distribution by sampling simulation results.

\subsection{Rockfall damage}

The topography of the slope was implemented in the Rockyfor3D model through a $5 \mathrm{~m}$-resolution DEM while the parameters used to characterize the interactions between the block and the soil - soil mechanical properties (i.e. restitution coefficients) and soil roughness were described by the current land-use and land-cover (LULC) pattern of Crolles (Fig. 2E [31,48]). LULC patchiness was derived, according to the cadastral map, from aerial photo interpretation using standard photographic keys (i.e., tone, texture, pattern, shape and size) as well as information available from the French digital cadaster database. Soil types (e.g., fine soil material or bedrock) and roughness parameters were associated with each LULC class [48].

At Le Brocey scale, a total of 6371 potential rockfall sources were mapped on the DEM, and for each of those, 10,000 rockfall simulations with volumes randomly extracted between $1 \mathrm{~m}^{3}$ and $20 \mathrm{~m}^{3}$ were simulated. To provide information on rock propagation at any location of the study site, the slope was divided in 4700 cells $z$ of $10 \times 10 \mathrm{~m}^{2}$ and rockfall energies were stored as:

$E(S, z)= \begin{cases}E(S, z) & \text { if } S \cap z \\ 0 & \text { if } S \cap z=\{\varnothing\}\end{cases}$

where $E$ is the kinetic energy (in Joules) of the block in a certain position $z$ along the slope for rockfall simulation $S$. Similarly, rockfall volume and simulation ID associated to each energy value were stored (Fig. 3A).

Following Eq. (9), energies resulting from the Rockyfor3D model were derived in term of degree of loss. Furthermore, a typical structural element characterized by a floor area of $100 \mathrm{~m}^{2}$ ( $Z$, according to DEM resolution) was associated to each of the 4700 cells $z$ constituting the slope. As we disregard the impact location of rockfalls on structures [50], their exposure was directly provided by the reach probability, so that $q(z)=1$. Consequently, damages were expressed in terms of destroyed surface (in $\mathrm{m}^{2}$ ) and evaluated at each cell along the slope for each simulation (Fig. 3A).

\subsection{Risk estimates}

Rockfall risk values were numerically evaluated at each $10 \times 10 \mathrm{~m}^{2}$ cell of Le Brocey slope through the damage expectation and based on VaR and ES metrics. In that respect, we (i) extracted the damage values of a random sample of the total simulations that respects the rockfall volume distribution (GPD model; Eq. (8)) and (ii) compiled the damage distribution at each cell $z$ along the slope (Fig. 3B).

\subsubsection{Rockfall risk from expected damages}

With respect to Eq. (1), the mean annual surface destroyed per year $\left(\mathrm{m}^{2} / \mathrm{yr}\right)$ was estimated as:

$\bar{R}_{z}=q(z) \times Z \times \lambda \times \bar{d}_{z}$,

where $\bar{d}_{z}$ correspond to the mean damage on element at risk $z$ evaluated all over the retained simulations sample.

\subsubsection{Quantile-based rockfall risk values}

Here, rockfall risk values were estimated based on VaR and ES metrics. Following Eq. (5) and Eq. (6), local ES and VaR damage values were computed for fixed $\alpha$-values corresponding to specific temporal 
horizons $t$ (Eq. (7)). Finally, with respect to Eq. (1), local damage values corresponding to VaR and ES were used to assess (i) the minimum and (ii) the average risk per year expected over $t$ years due to rockfall events involving worst-case scenarios as:

$R_{z}^{\mathrm{VaR}}=q(z) \times Z \times \frac{1}{t} \times \mathrm{VaR}_{\alpha}$

$R_{z}^{\mathrm{ES}}=q(z) \times Z \times \frac{1}{t} \times \mathrm{ES}_{\alpha}$,

where $t$ is the considered temporal horizon in years. Hence, the value-atrisk can as well be expressed as the annual risk that should not be exceeded by $\alpha \%$ of the rockfall events expected over $t$ years.

\subsection{Uncertainty quantification by bootstrap}

In order to quantify the robustness of our results to the sampling scheme (section 3.4), a bootstrap procedure was performed for $n=100$ iterations. At each step of the bootstrap procedure, a random sample of $3,353,158$ damage values conditional to the rockfall volume distribution (GPD model; Eq. (8)) was extracted from the total simulations. This especially accounts for the variability of the results, that may result from large volumes which induce high damage but are rare. Eventually, for each iteration $n$, we compiled the damage distribution at each cell $z$ along the slope and rockfall risk was quantified from the expected damage, the value-at-risk and the expected shortfall. The values from the bootstrap sampling were average at the cell scale and their dispersion was quantified through the standard deviation (SD) and the coefficient of variation (COV).

\section{Results}

\subsection{Rockfall hazard}

On average, over the 100 bootstrap iterations, $12 \%$ of the simulations $(392,229)$ propagate over 3031 out of the 4700 cells $z(64.5 \%)$ of Le Brocey slope. The remaining $88 \%$ are blocked in the centennial protection forest located upslope from the study site. Among the simulations reaching Le Brocey slope, on average, 112,610 and 719 are associated to volumes in the range $1-2 \mathrm{~m}^{3}$ and $19-20 \mathrm{~m}^{3}$, respectively. A reach probability $0<p_{z} \leq 0.10 \%$ is associated to $90 \%$ of the 3031 impacted cells $z$. The maximum value $\left(p_{z}=0.0133\right)$ is recorded in the upper part of the study site, at the contact of the protection forest.

Based on the temporal occurrence probability $\lambda$, Fig. 4A shows the spatial distribution of rockfall recurrence intervals at Le Brocey. In details, recurrence intervals lower than 1000 years are observed on 195 cells z (4\%). Unsurprisingly, these values are localized in rockfall corridors (where rockfall passages are the most frequent). The minimum value is estimated at 141 years $\left(p_{z}\right.$ max. $\left.=0.0133\right)$ in pixel $z_{A}$. For the remaining cells, recurrence intervals are higher and exceeded 1,000,000 years downslope, mostly below the current urban front limit (Fig. 4A).

The mean kinetic energy conditional to reach along rockfall trajectories exceeds $650 \mathrm{~kJ}$ for a large part of the simulations (Fig. 4B). The maximum energy $\left(73,000 \mathrm{~kJ}\right.$ for a block volume of $\left.20 \mathrm{~m}^{3}\right)$ is recorded in the lower part of the slope. High mean kinetic energies conditional to reach observed in the lower part of the slope are related to $(i)$ the limited roughness associated with grassland, wasteland as well as urbanized areas and (ii) to the steepness of the slope up to the level of the urban front. Furthermore, as the damage is close to 1 for kinetic energy $E$ exceeding $650 \mathrm{~kJ}$ (see Eq. (9)), a large proportion of simulations is associated to a damage value of $100 \mathrm{~m}^{2}$ conditional to reach.
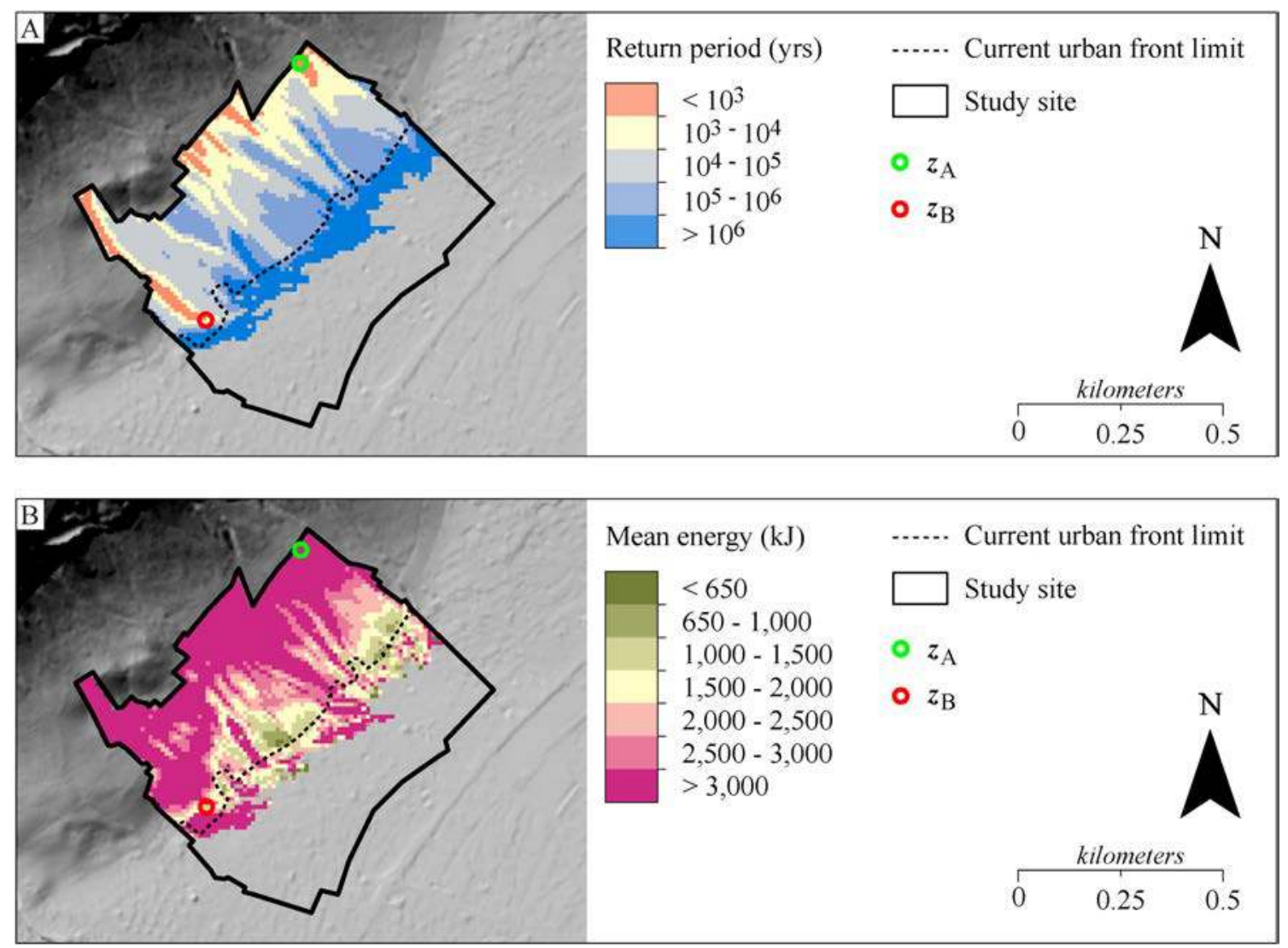

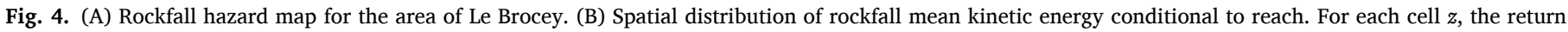
period (A) and the mean kinetic energy (B) have been evaluated over 100 bootstrap iterations (Section 3.5). 


\subsection{Quantitative analysis of rockfall risk}

\subsubsection{Damage distribution}

Damage distributions are computed for the 4700 cells z of Le Brocey slope. For illustration purposes, Fig. 5 focuses on the empirical damage distribution associated to two specific cells $z_{A}$ and $z_{B}$ and evaluated for to the bootstrap iteration $n=1$. Both cells are chosen according to their reach probability $p_{z}: p_{z_{A}}$ is the maximum reach probability observed on the slope $\left(p_{z_{A}}=0.0133\right)$ whereas $p_{z_{B}}$ is significantly lower $\left(p_{z_{B}}=0.003\right)$. Despite this difference, the mode of both damage distributions is $0 \mathrm{~m}^{2}$ and the probabilities $\operatorname{Pr}\left\{\mathrm{D}=0 \mathrm{~m}^{2}\right\}$ are 0.9866 and 0.9970 on $z_{A}$ and $z_{B}$, respectively. In addition, a second sharp increase in the damage cumulative distribution function is only observed on $z_{A}$, for a damage value of $100 \mathrm{~m}^{2}$. In detail, the probability for having a damage value of $100 \mathrm{~m}^{2}$ on $z_{A}$ is equal to 0.0013 .

\subsubsection{Expected damage}

Following Eq. (11) - which combines the rockfall occurrence frequency and the expected damage - we computed the risk to buildings expressed as the mean annual surface destroyed per year $\left(\mathrm{m}^{2} / \mathrm{yr}\right)$. Fig. 5 shows the expected damage associated to cells $z_{A}$ and $z_{B}$ for bootstrap iteration $n=1$. It equals to $1.1 \mathrm{~m}^{2}$ and $0.14 \mathrm{~m}^{2}$, respectively. Given the rockfall frequency $\lambda=0.53$ events/yr, risk as expected damage is evaluated to $0.58 \mathrm{~m}^{2} / \mathrm{yr}$ and $0.074 \mathrm{~m}^{2} / \mathrm{yr}$ at cells $z_{A}$ and $z_{B}$, respectively.

Fig. 6 represents the spatial distribution of the expected damage per year (in $\mathrm{m}^{2} / \mathrm{yr}$ ). In detail, it is $<0.01 \mathrm{~m}^{2} / \mathrm{yr}$ for $85 \%$ of the cells $z$ and values below $0.0005 \mathrm{~m}^{2} / \mathrm{yr}$ are mainly located in the currently urbanized area. Highest values are computed in rockfall corridors and exceed $0.5 \mathrm{~m}^{2} / \mathrm{yr}$ at two cells, including $z_{A}$.

\subsubsection{Value-at-risk}

The value-at-risk has been used to quantify the risk within fixed temporal horizons (Eq. (12)). It expresses the risk as the annual minimum damage expected over $t$ years due to worst-case rockfall scenarios. Again, for illustration purposes, results first focus on $z_{A}$ and $z_{B}$ cells.

Based on Eq. (7), worst-case rockfall events represent $1 \%(\alpha=0.99)$ of the damage distribution for a temporal horizon $t=200$ years, leading damage and risk values of $86 \mathrm{~m}^{2}$ and $0.43 \mathrm{~m}^{2} / \mathrm{yr}$ at $z_{A}$, respectively (Fig. 5A). Similarly, worst-case rockfall events represent $0.2 \%$ of the damage distribution for $t$ set at 1000 years $(\alpha=0.998)$. Based on this $\alpha$-quantile, damage and risk values are $25 \mathrm{~m}^{2}$ and $0.025 \mathrm{~m}^{2} / \mathrm{yr}$ at $z_{B}$, respectively (Fig. 5B). In other words, the risk induced by rockfall events expected over 200 years should never exceed $0.43 \mathrm{~m}^{2} / \mathrm{yr}$ with a probability of 0.99 at $z_{A}$. On $z_{B}$, there is a probability of 0.998 that rockfall events expected over 1000 years do not damage more than $0.025 \mathrm{~m}^{2} / \mathrm{yr}$.

Fig. 7 evaluates the damage and risk values corresponding to VaR as continuous function of the temporal horizon $t$ ranging between $1 / \lambda$ and $10^{6}$ years. For $z_{A}$, damages corresponding to VaR are $0 \mathrm{~m}^{2}$ for temporal horizons up to $t=141$ years (Fig. 7A). According to Eq. (7), this temporal horizon, associated with the probability of no damages, corresponds to an $\alpha$-quantile $<0.9866$. For $z_{B}$, the same probability is observed up to $t=634$ years (Fig. 7C) and $\alpha$-quantiles $<0.997$. High
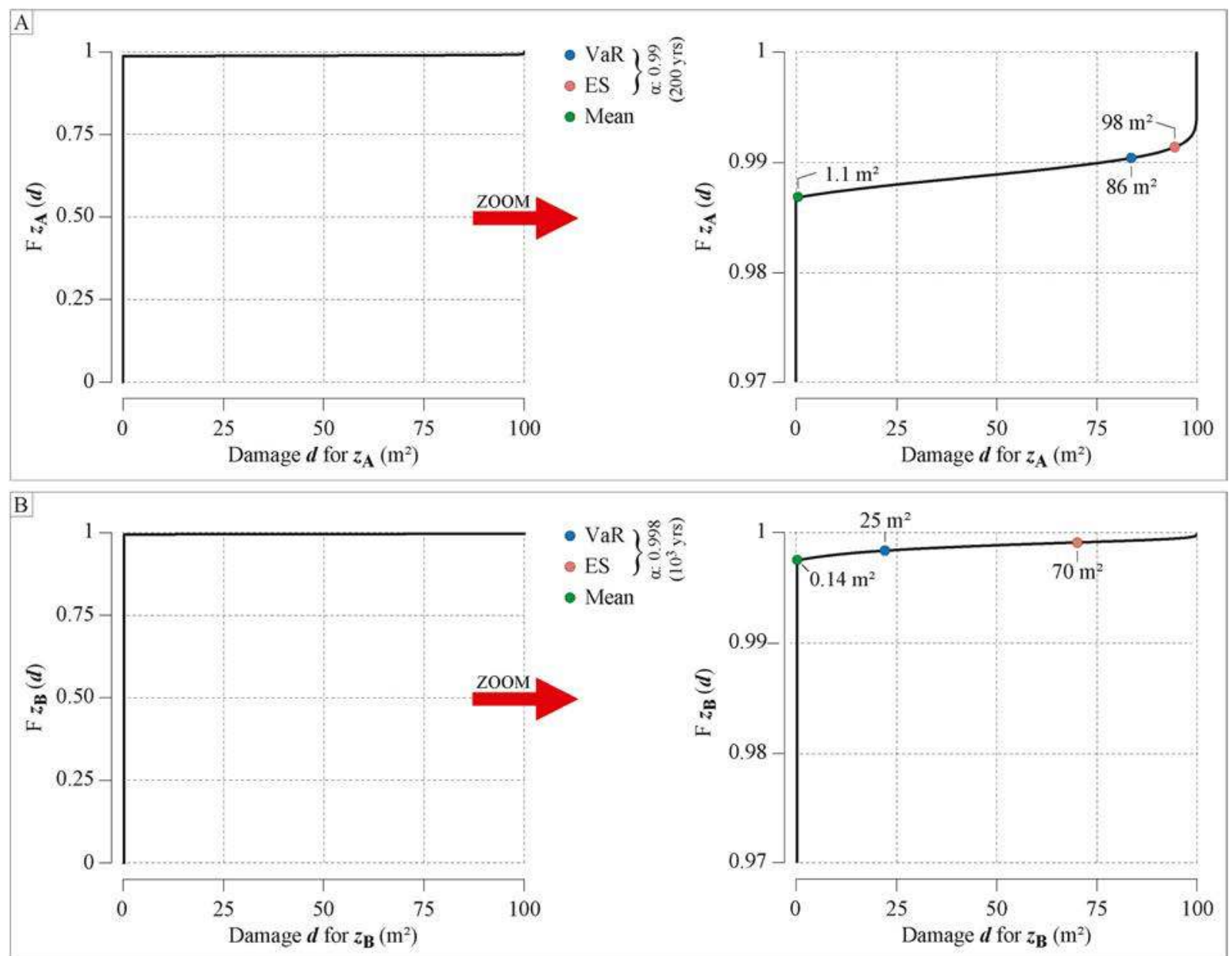

Fig. 5. Rockfall cumulative damage distributions at $z_{A}(\mathrm{~A})$ and $z_{B}$ (B) cells for the bootstrap iteration $n=1$ (Section 3.5). For each distribution, the value-at-risk (blue dot) and the expected shortfall (red dot) have been computed for temporal horizons $t=200$ years $(\alpha=0.99)$ on $z_{A}$ and $t=1000$ years $(\alpha=0.998)$ on $z_{B}$. Results are compared with the mean damage (green dot). 


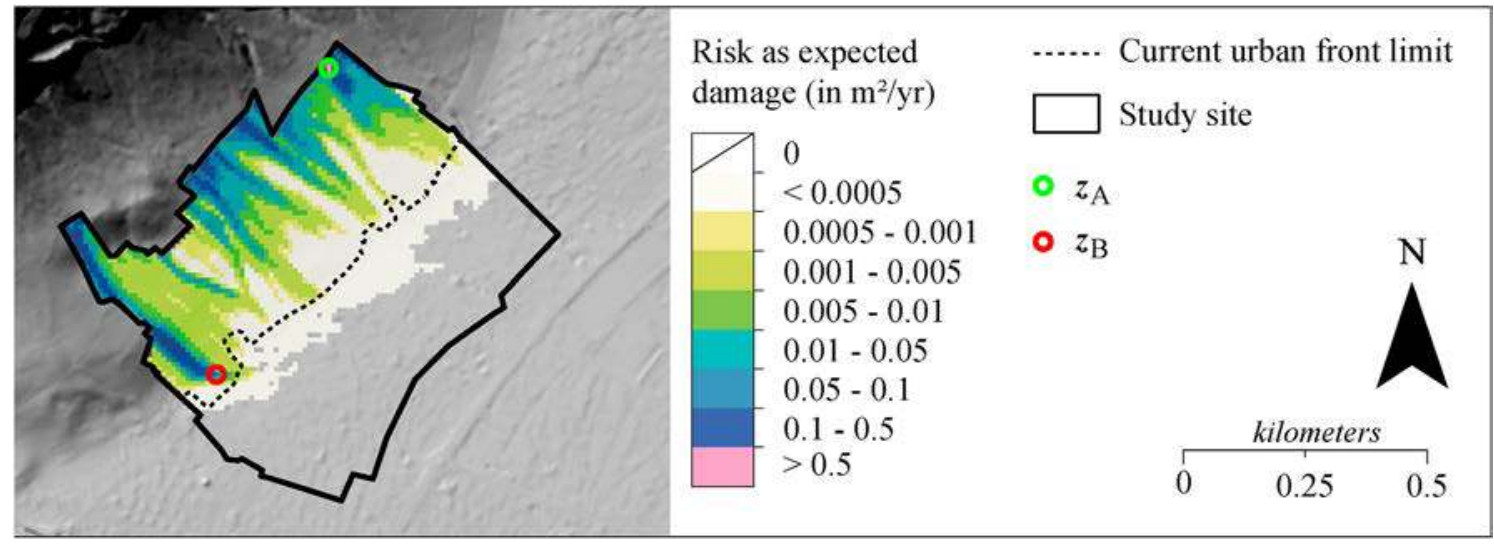

Fig. 6. Map of the risk expressed as the expected damage (in $\mathrm{m}^{2}$ destroyed per year) at Le Brocey. For each cell $z$, it has been computed over 100 bootstrap iterations (Section 3.5).
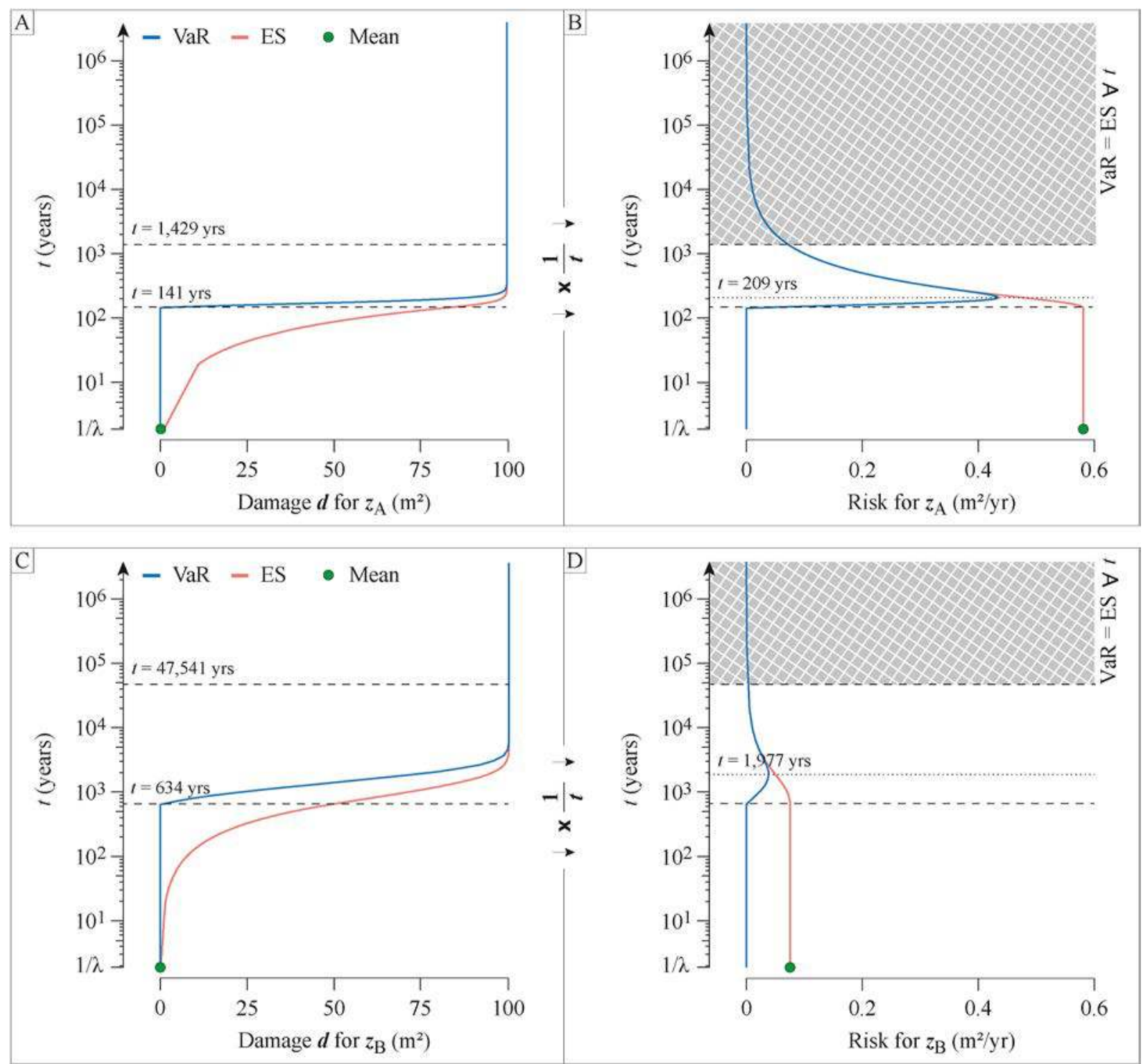

Fig. 7. Rockfall damage (A, C) and risk (B, D) as function of the temporal horizon $t$ at $z_{A}$ and $z_{B}$ cells based on the value-at-risk and the expected shortfall. All curves were evaluated for the bootstrap iteration $n=1$ (Section 3.5). 
rockfall energies observed at Le Brocey combined with the vulnerability curve of Agliardi et al. [1], result in a sharp increase of damage distributions from 0 to $100 \mathrm{~m}^{2}$ for horizon above 141 years at $z_{A}$ and 634 years at $z_{B}$. Damages reach systematically $100 \mathrm{~m}^{2}$ when $t$ exceeds 1429 years (Fig. 7A), 47,541 years (Fig. 7C) at $z_{A}$ and $z_{B}$, respectively. Consequently, $R_{z}^{\mathrm{VaR}}$ reaches a maximum value for $t=209$ years $(0.43$ $\mathrm{m}^{2} / \mathrm{yr}, z_{A}$; Fig. 7B) and $t=1977$ years $\left(0.038 \mathrm{~m}^{2} / \mathrm{yr}, z_{B}\right.$; Fig. 7D) and tends towards $0 \mathrm{~m}^{2} / \mathrm{yr}$ for longer time periods.

Fig. 8 shows the spatial distribution of $R_{z}^{\mathrm{VaR}}$ for specific temporal horizons $t$ set to 100 years $(\alpha=0.98), 300$ years ( $\alpha=0.994), 1000$ years $(\alpha=0.998)$ and 10,000 years $(\alpha=0.9998)$. For a temporal horizon $t$ of 100 years, $R_{z}^{\mathrm{VaR}}$ is null for each cell of the studied area (Fig. 8A). In other words, the probability that damages occur on any cell over 100 years is $<0.02(1-\alpha)$. Similarly, for a temporal horizon of 300 years, the probability for risk values corresponding to VaR to be null is 0.994 for 4683 out of 4700 cells (Fig. 8B). Remaining cells associated with $R_{z}^{\mathrm{VaR}}$ ranging between $0.1 \mathrm{~m}^{2} / \mathrm{yr}$ and $0.5 \mathrm{~m}^{2} / \mathrm{yr}$ are mainly located in the upper part of rockfall corridors.

As expected, the number of cells characterized by non-null $R_{z}^{\mathrm{VaR}}$ increases downslope preferentially along rockfall corridors for $t=1000$ (Fig. 8C), 10,000 years (Fig. 8D). For the latter horizon, damage values corresponding to VaR are equal to $100 \mathrm{~m}^{2}$ for 16 cells mainly located in the upper part of the study site at the contact of the protection forest (hatched area on map, Fig. 8D). In other words, as the damage values corresponding to VaR is $100 \mathrm{~m}^{2}$, worst-case scenarios (over 10,000 years) will necessarily fully destroy the building-like infrastructure present in these cells. Finally, our map shows that $99.98 \%$ of the events expected over 10,000 years will not reach the level of the current urban front.

\subsubsection{Expected shortfall}

Based on the expected shortfall (Eq. (13)), the damage and risk values expected at $z_{A}$, over a 200 -year horizon, are $98 \mathrm{~m}^{2}$ and $0.49 \mathrm{~m}^{2}$ / yr, respectively (Fig. 5A). They obviously exceed the damage and risk values corresponding to $\operatorname{VaR}\left(86 \mathrm{~m}^{2}\right.$ and $0.43 \mathrm{~m}^{2} / \mathrm{yr}$ ). Similarly, at $z_{B}$, damage and risk values corresponding to $\mathrm{ES}\left(70 \mathrm{~m}^{2}\right.$ and $\left.0.07 \mathrm{~m}^{2} / \mathrm{yr}\right)$ for $t=1000$ years are approximately 3 times higher than damage and risk values corresponding to $\operatorname{VaR}\left(25 \mathrm{~m}^{2}\right.$ and $0.025 \mathrm{~m}^{2} / \mathrm{yr}$; Fig. $\left.5 \mathrm{~B}\right)$.

Fig. 7B and D show the evolution of $R_{z}^{\mathrm{ES}}$ for temporal horizons $t$ between $1 / \lambda$ years and $10^{6}$ years. Unsurprisingly, in view of Eq. (7) and Appendix B, $R_{z}^{\mathrm{ES}}$ is equal to the expected value for $t=1 / \lambda$ and as long as $\alpha<\operatorname{Pr}\left\{\mathrm{D}=0 \mathrm{~m}^{2}\right\}$. The differences between $R_{z}^{\mathrm{ES}}$ and $R_{z}^{\mathrm{VaR}}$ are maximum below 141 years $\left(0.53 \mathrm{~m}^{2} / \mathrm{yr}\right)$ at $z_{A}$ (Fig. $7 \mathrm{~A}$ and B) and 634 years $(0.075$ $\mathrm{m}^{2} / \mathrm{yr}$ ) at $z_{B}$ (Fig. $7 \mathrm{C}$ and D). Above these temporal horizons, both risk distributions rapidly converge. They are strictly equal (shaded area on Fig. 7B, D) when $\alpha>\operatorname{Pr}\left\{\mathrm{D}<100 \mathrm{~m}^{2}\right\}$, for $t>1429$ years $\left(z_{A}\right)$ and $t>$ 47,541 years $\left(z_{B}\right)$.

Maps presented in Fig. 9 show the spatial distribution of $R_{z}^{\mathrm{ES}}$ for the $2 \%$ (100 years), $0.6 \%$ (300 years), $0.2 \%$ (1000 years) and $0.02 \%$ (10,000 years) of worst-case scenarios. These maps using the expected-shortfall as risk measure strongly differ from those computed with the value-atrisk (Fig. 8). Again, in view of Appendix B, the ES-map at a temporal horizon of 100 years is strictly similar to the one computed using the arithmetic mean (Fig. 6). Maps computed for 300 years, 1000 years and 10,000 years show similar risk patterns but differ at cells were $R_{z}^{\mathrm{VaR}}$ is not equal to $0 \mathrm{~m}^{2} / \mathrm{yr}\left(\alpha>\operatorname{Pr}\left\{\mathrm{D}=0 \mathrm{~m}^{2}\right\}\right.$; Fig. $\left.8 \mathrm{~B}, \mathrm{C}, \mathrm{D}\right)$. More interestingly, regardless of temporal horizons, low risks values corresponding to ES are computed in cells located below the current urban front. This illustrates the non-null risk incurred in the currently inhabited area.

\subsection{Bootstrapping}

Fig. 10 shows the standard deviation (SD) and the coefficient of variation (COV) for ES and temporal horizons $t=100$ years, 1000 years and 10,000 years. The standard deviations do not exceed $3 \mathrm{e}^{-3}$ at an horizon of 100 years (Fig. 10A). As damages tend more systematically to $100 \mathrm{~m}^{2}$ through time, this minimum value decreases for 1000 and 10,000 years temporal horizons (Fig. 10C, E). Obviously, the coefficient of variation which represents the ratio between the SD and the average of risk decreases through time (Fig. 10B, D, F). This demonstrates the sufficient robustness of our results to the sampling of the volume distribution.

\section{Discussion, conclusion and outlooks}

\subsection{Main methodological outcomes of the work}

Classically, risk is evaluated through the standard damage expectation, widely adopted since it is intuitive, easy to compute and interpret, as well as additive. Yet, a major drawback lies in its inability to capture the extent of consequences due to rare events. In addition, it provides a unique risk estimate, which does not account for different short/long term constraints or trade-offs faced by risk decision-makers. To better assess the risk from extreme events, we proposed, in this study, an innovative approach where rockfall risk is estimated based on quantilebased measures. Also, in order to make it usable in area where new constructions are envisaged, we evaluated these quantile-based risk measures as well as the expected damage as continuous function of space on an individual basis at each location along a slope potentially suitable for new buildings [3]. For this purpose, our approach requires the complete distribution of damages, individually assessed by combining rockfall simulations with the rockfall volume distribution of block volumes in the range $1-20 \mathrm{~m}^{3}$ and the physical vulnerability of potentially affected buildings.

Specifically, we introduced the value-at-risk (VaR) measure, which is nothing more than the $\alpha$-quantile of the distribution of damages [28]. Despite its high interest, it however fails to capture potential consequences beyond the confidence level $\alpha$ [51]. We therefore complemented our approach by introducing the expected-shortfall (ES), that aims at quantifying the consequences of events above the value-at-risk. Both value-at-risk and expected shortfall measures enable decision-makers to modulate their management according to different risk preferences: $\alpha$ close to 0 being more risk neutral, and $\alpha$ close to 1 more risk conservative [69]. More generally, VaR and ES measures enable the ranking and comparison of risk management options and leave to decision-makers the final decision, depending on their personality and on their political, social and/or budgetary constraints. Additionally, the approach developed here not only precisely assess the rockfall risk due to extreme events, but also provide rockfall risk maps over different temporal horizons. Hence, our approach may provide valuable tools for future land-use planning and decision-making, and more widely, determine the right balance between safety and sustainability in rockfall prone areas.

Eventually, in the existing literature, rockfall hazard and risk assessments are classically based on trajectory models. However, given the complexity of the rockfall process (with respect i.e., rebounds, deviation and damage of energy induced by obstacles [20]), multiple simulations are required to properly assess the distributions of rockfall trajectories and energies in each cell of our study site. In that respect, we developed a bootstrap procedure that (1) enables to integrate a large spectrum of potential rockfall events while (2) optimizing data storage and processing. Based on this process, 3,358,158 simulations were sampled 100 -times from the $63,710,000$ trajectories stored from RF3D simulations. In the absence of bootstrapping, nearling results of similar steepness would have required a number of simulations more than 5 -times higher $(3,358,158 \times 100)$. We believe that this approach could be even more relevant for other natural hazards for which only rare events lead to a total destruction of impacted buildings. 
...... Current urban front limit Study site

$\operatorname{VaR}\left(\mathrm{m}^{2} / \mathrm{yr}\right)$

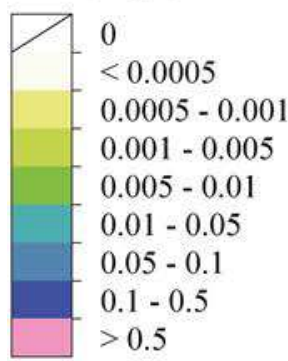

$\mathrm{VaR}=\mathrm{ES} \forall t$
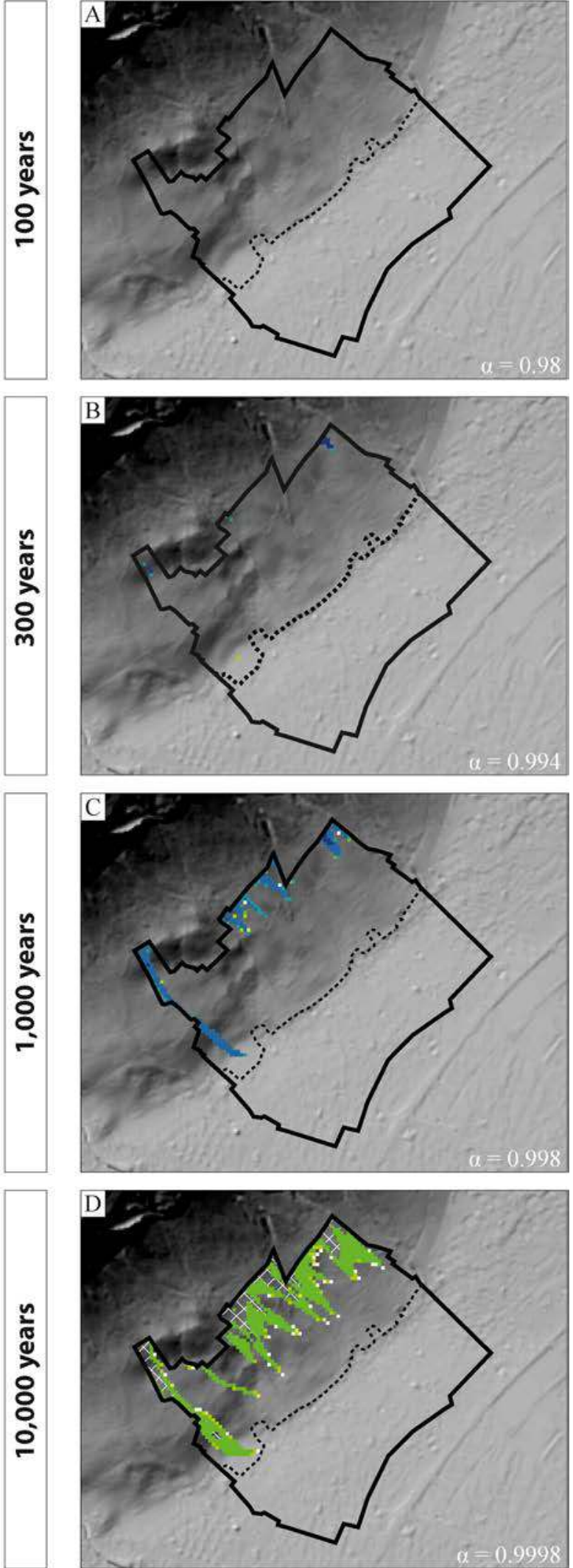

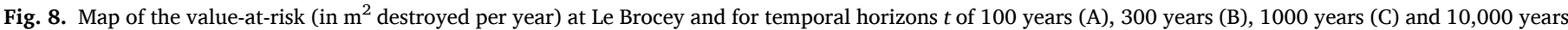
(D). For each cell, the mean VaR has been computed over 100 bootstrap iterations (Section 3.5). 
...... Current urban front limit Study site

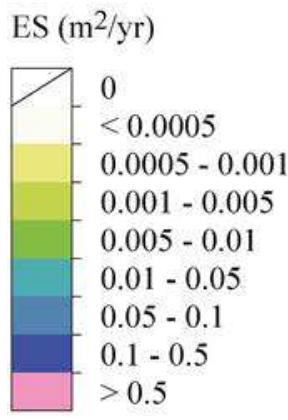

$\mathrm{VaR}=\mathrm{ES} \forall t$
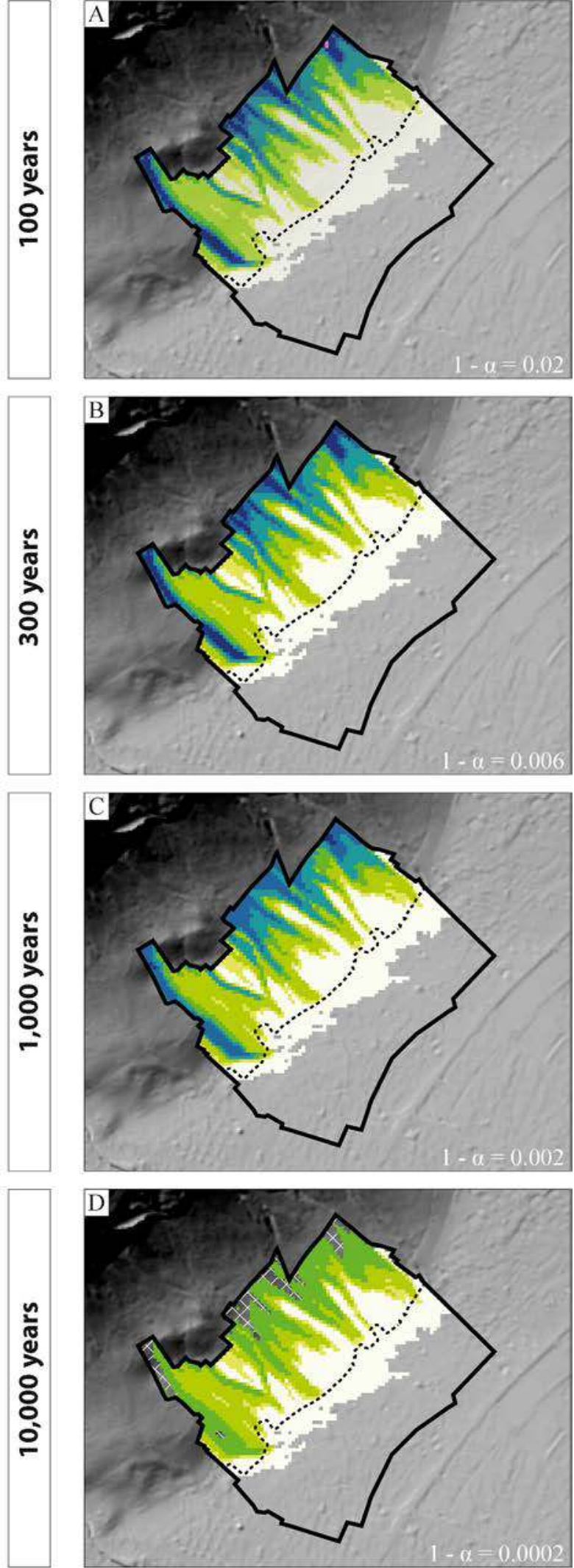

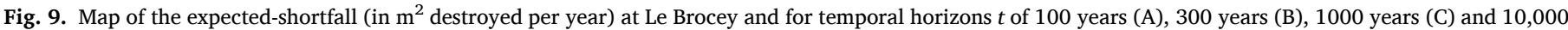
years (D). For each cell, the mean ES has been computed over 100 bootstrap iterations (Section 3.5). 
$\operatorname{SD}[\mathrm{ES}]\left(\mathbf{m}^{2} / \mathbf{y r}\right)$
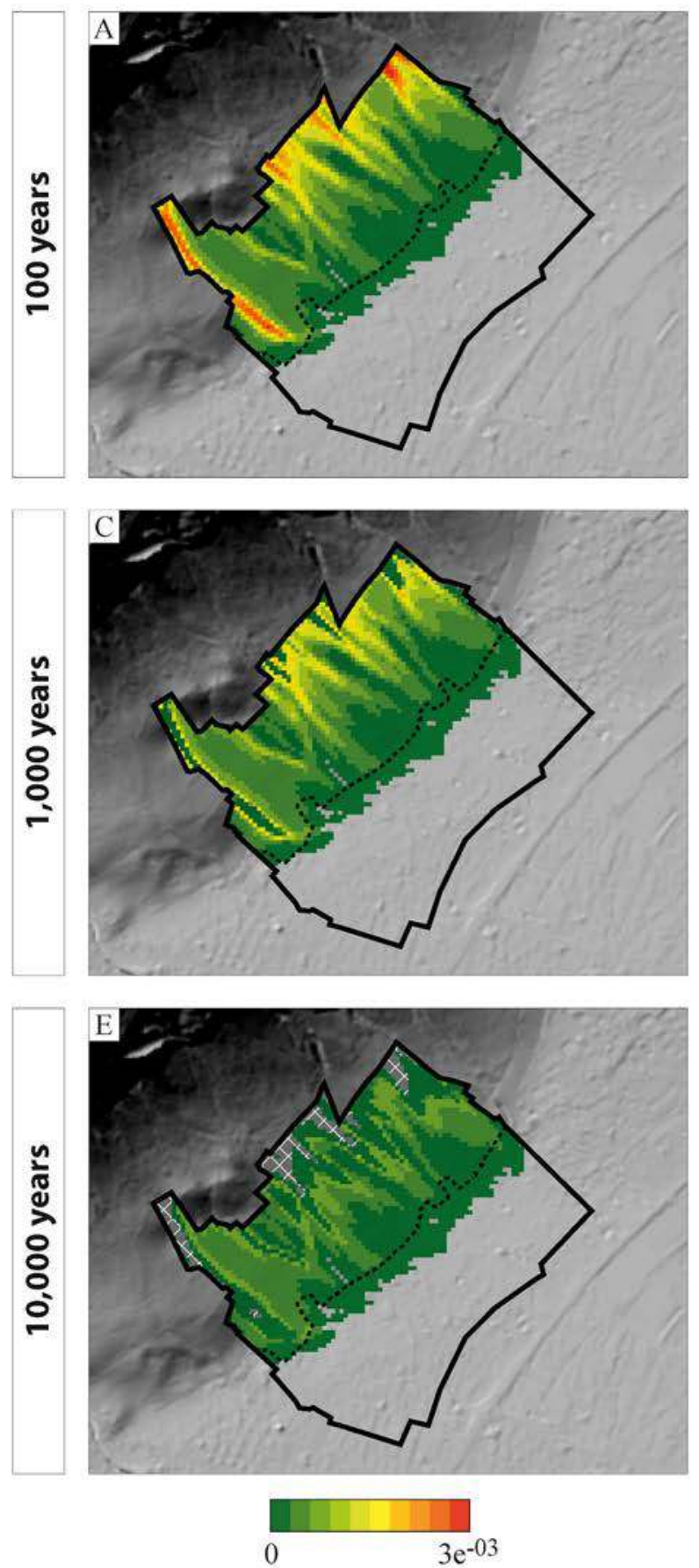
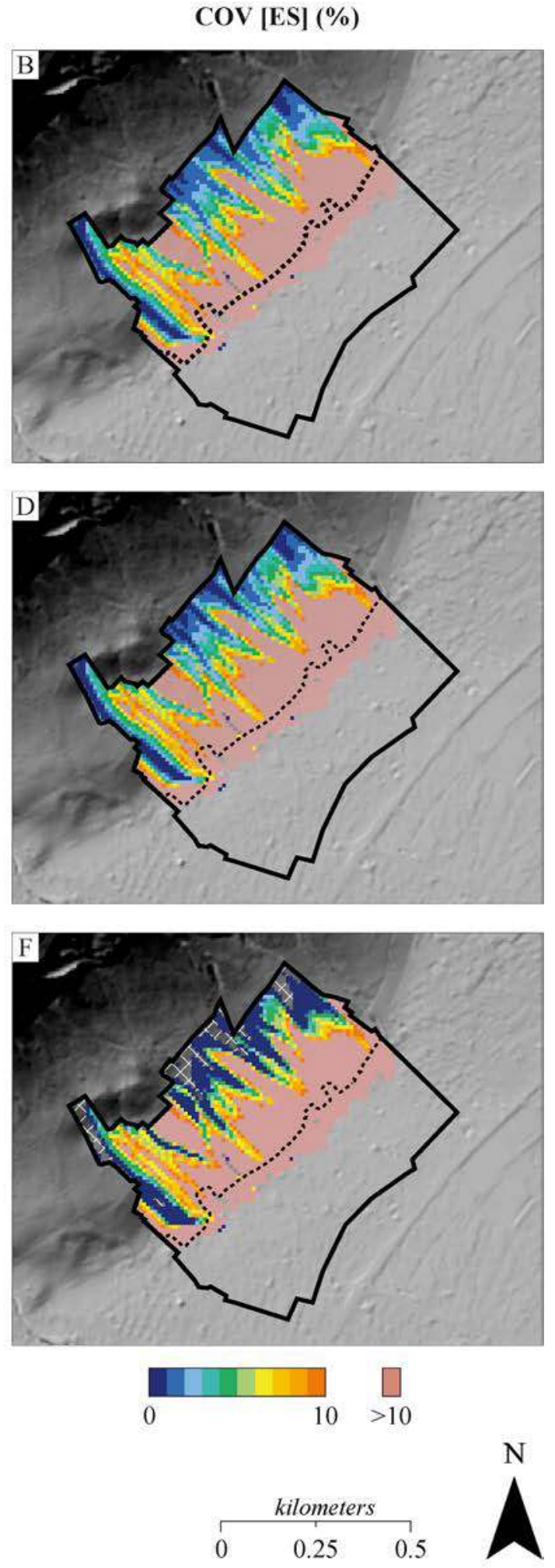

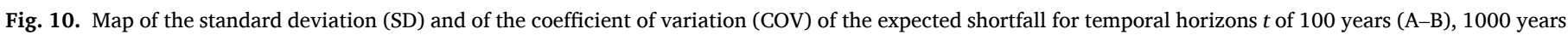

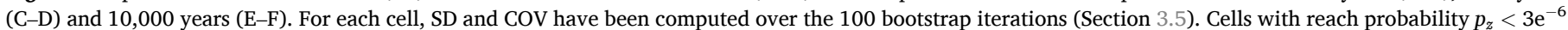
were excluded.

\subsection{Implications for the case study}

For illustration, our approach has been implemented at Le Brocey slope, in the municipally of Crolles, where numerous rockfalls have been reported since the beginning of the 20th century [31]. Based on $\alpha$-quantiles deduced from fixed temporal horizons $t$ ranging between 100 years and 10,000 years, risk values risk values corresponding to VaR and ES have been quantified at each location along the slope. The resulting panel of individual VaR-risk maps demonstrates that no risk exists as long as $t<100$ years. Above this temporal horizon, the number 
of at-risk locations, and, hence, potentially threatening buildings, increases downslope, preferentially along rockfall corridors, but remains very limited. The absence of risk associated with a large majority of locations results from (1) the low probability for a rockfall event to propagate downslope due to the presence of the protection forest. This is particularly true given that the forest has significant impacts on rockfall propagation for lower volumes $\left(<3 \mathrm{~m}^{3}[21,22,63]\right)$, that represent $80 \%$ of the rockfall simulations at Le Brocey. Similarly, (2) individual rockfall events have a limited spatial extent as function of the trajectory of the block and its size. As a consequence, the latter generate very localized damages contrary to other mass movements such as snow avalanches, landslides, or seismic events, which are susceptible to produce widespread damages within the extent of a single event $[11,37,68]$.

However, we observed that for a large proportion of the cells, rockfall damages lead to the near-total destruction of potentially exposed buildings as soon as they are hit. This results from another specificity of rockfall processes, namely high energies during their motion, that mainly cause total destruction in case of an impact on a building-like structure (damage probability of 1 [1]). Moreover, individual ES maps highlight that rockfall risk is widely spread in Le Brocey but remains strictly equal to the expected damage value as long as $\alpha<$ $\operatorname{Pr}\left\{\mathrm{D}=0 \mathrm{~m}^{2}\right\}$ (or risk value corresponding to VAR equals to $0 \mathrm{~m}^{2} / \mathrm{yr}$ ). This means that the expected damage gives a first insightful risk estimate for a large part of the study area but leads to a significant overestimation of the risk for temporal horizons $t$ above $1 / \lambda$ (rockfall return period).

Overall, these results suggest that rockfall risk at Le Brocey is mainly located in rockfall corridors. However, analysis of extreme events demonstrates that a large proportion of Le Brocey slope (including currently inhabited area) is subject to potential rockfall damages. Furthermore, given the high energies of events during their propagation, any impact with a building-like structure should lead to its near-total destruction. By quantifying the risk through alternative measures, our results thus complement the current knowledge and understanding of rockfall risk in the municipality of Crolles, opening the door to a more efficient and suitable risk assessment and management.

\subsection{Outlooks for further work}

In the field of natural hazards, simple statistics such as the arithmetic average, the maximum value, or a percentile [47] are still employed to characterize the risk undertaken in a specific context. On the contrary, practitioners in insurance and other financial institutions are used to deal with more advanced risk measures [7], and a large range of approaches to measuring risk has been developed in recent decades [51]. In this study, we introduced the most popular financial risk measures (i. e., the value-at-risk and the expected shortfall) for quantifying rockfall risk and demonstrated their added value for risk management. Such developments could be in the future extended to other natural hazards, such as other landslide types or flooding [8]. Furthermore, an optimal value of the $\alpha$-quantile could be determined by implementing the approach on different case studies and coupling it with interviews or surveys [67]. Also the choice of mitigation strategies could be optimized taking into account the behavior of decision-maker facing risk [25]. Similarly, based on acceptability thresholds $[35,43,66]$, refined rockfall zoning maps could be proposed. Eventually taking into account potential changes in rockfall activity and propagation related to, e.g., landscape evolution (very likely to occur within decades), would be an interesting perspective to enlarge relevance of the risk analysis in local contexts submitted to drastic changes.

\section{Declaration of competing interest}

The authors declare that they have no known competing financial interests or personal relationships that could have appeared to influence the work reported in this paper.

\section{Acknowledgments}

This research was financially supported by a Ph.D. grant from RhôneAlpes region (ARC Environnement 3), the C2ROP (Chutes de blocs, Risques Rocheux, Ouvrages de Protection) national research project, the Irstea ZORRINO (Zonage réglementaire du risque en montagne par optimisation des pertes) project and the French National Research Agency in the Investissements d'Avenir program (ANR-15-IDEX-02) within the cross-disciplinary Risk@Univ. Grenoble Alpes program. INRAE is member of Labex Osug@2020.

Appendices.

Appendix A. Determination of the confidence level $\alpha$ for a predetermined temporal horizon $t$

The annual probability that $k$ rockfall events lead a damage $D \leq d$ is given by:

$\operatorname{Pr}_{a n}(D \leq d)=\sum_{k} \operatorname{Pr}(K=k) \operatorname{Pr}(D \leq d)^{\mathrm{k}}$,

with the random variable $K$ describing the number of rockfall events occurring each year.

Following extreme value theory, $K \sim P o(\lambda)$ with $\lambda$ the average number of rockfall events per year [57], $P o()$ denoting the Poisson distribution. The annual probability is thus given by:

$\operatorname{Pr}_{a n}(D \leq d)=\sum_{k}\left[\frac{\lambda^{k}}{k !} e^{-\lambda}\right] \mathscr{L}(d)^{k}$

Using a Taylor expansion and a first-order approximation,

$\operatorname{Pr}_{a n}(D \leq d)=e^{-\lambda} \sum_{k} \frac{[\lambda \mathscr{L}(d)]^{k}}{k !}=e^{-\lambda} e^{\lambda \mathscr{L}(d)} \approx 1-\lambda[1-\mathscr{L}(d)]$

Hence, the annual probability that rockfall events lead a damage $D>d$ is:

$\operatorname{Pr}_{a n}(D \leq d)=1-\operatorname{Pr}_{a n}(D \leq d)=\lambda[1-\mathscr{L}(d)]$.

The time period $t$ between two events that lead a damage $D>d$ corresponds to: 
$t=\frac{1}{\operatorname{Pr}_{a n}(D>d)}=\frac{1}{\lambda[1-\mathscr{L}(d)]}$.

Conversely, the mean damage $d$ over the period $t$ is:

$d=\mathscr{L}^{-1}(\alpha)$,

where

$\alpha=1-\frac{1}{\lambda t}$.

Appendix B. Annualized expected shortfall for $\alpha$ lower than $\operatorname{Pr}\{D=0\}$

Following Eq. (1), the annualized expected damage is given by:

$\bar{R}_{z}=q(z) \times Z \times \lambda \times \mathbb{E}\left[D_{z}\right]$.

By distinguishing null- and non null-damages, the mean risk per year can also be expressed as:

$\bar{R}_{z}=q(z) \times Z \times \lambda \times \operatorname{Pr}\{D>0\} \times \mathbb{E}[D>0]$,

where $\operatorname{Pr}\{D>0\}$ is the probability of having non-null damages.

According to Eq. (7), the temporal horizon $t$ can be expressed as:

$t=\frac{1}{\lambda(1-\alpha)}$,

and consequently the annualized expected shortfall is:

$R_{z}^{\mathrm{ES}}=q(z) \times Z \times \lambda(1-\alpha) \times \mathrm{ES}_{\alpha}$.

The probability of $D>0$ given $D>D_{\alpha}$ is obtained from conditional probability rules:

$\operatorname{Pr}\left\{D>0 \mid D>D_{\alpha}\right\}=\frac{\operatorname{Pr}\left\{D>0 \cap D>D_{\alpha}\right\}}{\operatorname{Pr}\left\{D>D_{\alpha}\right\}}=\frac{\operatorname{Pr}\{D>0\}}{\operatorname{Pr}\left\{D>D_{\alpha}\right\}}$.

Finally, knowing that:

$\operatorname{Pr}\left\{D>D_{\alpha}\right\}=(1-\alpha)$,

for $0 \leq \alpha<\operatorname{Pr}\{D=0\}$, the annualized expected shortfall $R_{z}^{\mathrm{ES}}$ can be rewritten as:

$$
\begin{gathered}
R_{z}^{\mathrm{ES}}=q(z) \times Z \times \lambda(1-\alpha) \times \operatorname{Pr}\left\{D>0 \mid D>D_{\alpha}\right\} \times \mathbb{E}[D>0] \\
=q(z) \times Z \times \lambda(1-\alpha) \times \frac{\operatorname{Pr}\{D>0\}}{1-\alpha} \times \mathbb{E}[D>0] \\
=q(z) \times Z \times \lambda \times \operatorname{Pr}\{D>0\} \times \mathbb{E}[D>0] \\
=\bar{R}_{z} .
\end{gathered}
$$

In other words, for $0 \leq \alpha<\operatorname{Pr}\{D=0\}$, the annualized expected shortfall coincides with the annualized expected damage.

\section{References}

[1] F. Agliardi, G.B. Crosta, P. Frattini, Integrating rockfall risk assessment and countermeasure design by 3d modelling techniques, Nat. Hazards Earth Syst. Sci. 9 (4) (2009) 1059-1073, https://doi.org/10.5194/nhess-9-1059-2009.

[2] M. Ansari, M. Ahmad, R. Singh, T. Singh, Rockfall assessment near saptashrungi gad temple, nashik, Maharashtra, India, Int. J. Disaster Risk Reduct. 2 (2012) 77-83, https://doi.org/10.1016/j.ijdrr.2012.09.002.

[3] P. Arnalds, K. Jonasson, S. Sigurosson, Avalanche hazard zoning in Iceland based on individual risk, Ann. Glaciol. 38 (2004) 285-290, https://doi.org/10.3189/ 172756404781814816.

[4] P. Assali, Modélisation géostructurale 3d de parois rocheuses par lasergrammétrie et photogrammétrie terrestres en milieu ferroviaire, Bull. Eng. Geol. Environ. 74 (4) (2015) 1255-1265, https://doi.org/10.1007/s10064-014-0711-8.

[5] T. Aven, The reconceptualization of risk, in: Routledge Handbook of Risk Studies, Routledge, 2016, pp. 76-90.

[6] A. Badoux, N. Andres, F. Techel, C. Hegg, Natural hazard fatalities in Switzerland from 1946 to 2015, Nat. Hazards Earth Syst. Sci. 16 (12) (2016) 2747-2768, https://doi.org/10.5194/nhess-16-2747-2016.
[7] J. Belles-Sampera, M. Guillén, M. Santolino, The use of flexible quantile-based measures in risk assessment, Commun. Stat. Theor. Methods 45 (6) (2016) 1670-1681, https://doi.org/10.1080/03610926.2014.938829.

[8] J. Bernier, Décisions et comportement des décideurs face au risque hydrologique, Hydrol. Sci. J. 48 (3) (2003) 301-316, https://doi.org/10.1623/ hysj.48.3.301.45284.

[9] F. Bourrier, J. Baroth, S. Lambert, Accounting for the variability of rock detachment conditions in designing rockfall protection structures, Nat. Hazards 81 (1) (2016) 365-385, https://doi.org/10.1007/s11069-015-2084-0.

[10] C.M. Bunce, D.M. Cruden, N.R. Morgenstern, Assessment of the hazard from rock fall on a highway, Can. Geotech. J. 34 (3) (1997) 344-356, https://doi.org/ 10.1139/t97-009.

[11] F. Cappabianca, M. Barbolini, L. Natale, Snow avalanche risk assessment and mapping: a new method based on a combination of statistical analysis, avalanche dynamics simulation and empirically-based vulnerability relations integrated in a gis platform, Cold Reg. Sci. Technol. 54 (3) (2008) 193-205, https://doi.org/ 10.1016/j.coldregions.2008.06.005.

[12] S. Coles, An Introduction to Statistical Modeling of Extreme Values. Springer Series in Statistics, Springer London, London, 2001, https://doi.org/10.1007/978-14471-3675-0. 
[13] J. Corominas, R. Copons, J. Moya, J.M. Vilaplana, J. Altimir, J. Amigo, Quantitative assessment of the residual risk in a rockfall protected area, Landslides 2 (4) (2005) 343-357, https://doi.org/10.1007/s10346-005-0022-z.

[14] J. Corominas, G. Matas, R. Ruiz-Carulla, Quantitative analysis of risk from fragmental rockfalls, Landslides 16 (1) (2019) 5-21, https://doi.org/10.1007/ s10346-018-1087-9.

[15] J. Corominas, O. Mavrouli, Rockfall quantitative risk assessment, in: S. Lambert, F. Nicot (Eds.), Rockfall Engineering, John Wiley \& Sons, Inc., Hoboken, NJ, USA 2013, pp. 255-301, https://doi.org/10.1002/9781118601532.ch8.

[16] J. Corominas, C. van Westen, P. Frattini, L. Cascini, J.-P. Malet, S. Fotopoulou, F. Catani, M. Van Den Eeckhaut, O. Mavrouli, F. Agliardi, K. Pitilakis, M.G. Winter M. Pastor, S. Ferlisi, V. Tofani, J. HervA $;$ s, J.T. Smith, Recommendations for the quantitative analysis of landslide risk, Bull. Eng. Geol. Environ. 73 (2014) 209-263, https://doi.org/10.1007/s10064-013-0538-8.

[17] D. Cruden, D.J. Varnes, Landslide types and processes. Special report - national research council, Transport. Res. Board 247 (1996) 36-75.

[18] V. De Biagi, M.L. Napoli, M. Barbero, D. Peila, Estimation of the return period of rockfall blocks according to their size, Nat. Hazards Earth Syst. Sci. 17 (1) (2017) 103-113, https://doi.org/10.5194/nhess-17-103-2017.

[19] L. Dorren, Rockyfor3d, (v5.1) Revealed Transparent Description of the Complete 3d Rockfall Model, ecorisQ paper, 2012, p. 32.

[20] L.K. Dorren, F. Berger, C. le Hir, E. Mermin, P. Tardif, Mechanisms, effects and management implications of rockfall in forests, For. Ecol. Manag. 215 (1-3) (2005) 183-195, https://doi.org/10.1016/j.foreco.2005.05.012.

[21] S. Dupire, F. Bourrier, J.-M. Monnet, S. Bigot, L. Borgniet, F. Berger, T. Curt, Nove quantitative indicators to characterize the protective effect of mountain forests against rockfall, Ecol. Indicat. 67 (2016) 98-107, https://doi.org/10.1016/j. ecolind.2016.02.023.

[22] S. Dupire, F. Bourrier, J.-M. Monnet, S. Bigot, L. Borgniet, F. Berger, T. Curt, The protective effect of forests against rockfalls across the French alps: influence of forest diversity, For. Ecol. Manag. 382 (2016) 269-279, https://doi.org/10.1016/j. foreco.2016.10.020.

[23] C. Dussauge-Peisser, A. Helmstetter, J.-R. Grasso, D. Hantz, P. Desvarreux, M. Jeannin, A. Giraud, Probabilistic approach to rock fall hazard assessment: potential of historical data analysis, Nat. Hazards Earth Syst. Sci. 2 (1/2) (2002) 15-26, https://doi.org/10.5194/nhess-2-15-2002.

[24] N. Eckert, C. Keylock, D. Bertrand, E. Parent, T. Faug, P. Favier, M. Naaim, Quantitative risk and optimal design approaches in the snow avalanche field: review and extensions, Cold Reg. Sci. Technol. $79-80$ (2012) 1-19, https://doi. org/10.1016/j.coldregions.2012.03.003.

[25] N. Eckert, M. Naaim, F. Giacona, P. Favier, A. Lavigne, D. Richard, F. Bourrier, E. Parent, Repenser les fondements du zonage réglementaire des risques en montagne « récurrents», La Houille Blanche (2) (2018) 38-67, https://doi.org/ $10.1051 / \mathrm{hb} / 2018019$.

[26] N. Eckert, E. Parent, T. Faug, M. Naaim, Optimal design under uncertainty of a passive defense structure against snow avalanches: from a general Bayesian framework to a simple analytical model, Nat. Hazards Earth Syst. Sci. 8 (5) (2008) 1067-1081, https://doi.org/10.5194/nhess-8-1067-2008.

[27] N. Eckert, E. Parent, T. Faug, M. Naaim, Bayesian optimal design of an avalanche dam using a multivariate numerical avalanche model, Stoch. Environ. Res. Risk Assess. 23 (8) (2009) 1123-1141.

[28] P. Embrechts, C. KlÂّ/4ppelberg, T. Mikosch, Modelling Extremal Events, Springer Berlin Heidelberg, Berlin, Heidelberg, 1997, https://doi.org/10.1007/978-3-64233483-2.

[29] S. Emmer, M. Kratz, D. Tasche, What is the best risk measure in practice? A comparison of standard measures, J. Risk 18 (2) (2015) 31-60, https://doi.org/ 10.21314/JOR.2015.318.

[30] T.H. Erismann, G. Abele, Dynamics of Rockslides and Rockfalls, Springer Berlin Heidelberg, Berlin, Heidelberg, 2001, https://doi.org/10.1007/978-3-662-046395.

[31] M. Farvacque, J. Lopez-Saez, C. Corona, D. Toe, F. Bourrier, N. Eckert, How is rockfall risk impacted by land-use and land-cover changes? insights from the French alps, Global Planet. Change 174 (2019) 138-152, https://doi.org/10.1016/ j.gloplacha.2019.01.009.

[32] M. Farvacque, J. Lopez-Saez, C. Corona, D. Toe, F. Bourrier, N. Eckert, Quantitative risk assessment in a rockfall-prone area: the case study of the Crolles municipality (Massif de la Chartreuse, French Alps), Géomorphologie: Relief Process. Environ. 25 (1) (2019) 7-19, https://doi.org/10.4000/geomorphologie.12778.

[33] P. Favier, D. Bertrand, N. Eckert, M. Naaim, A Reliability Assessment of Physical Vulnerability of Reinforced Concrete Walls Loaded by Snow Avalanches, 2014.

[34] P. Favier, D. Bertrand, N. Eckert, I. Ousset, M. Naaim, Assessing fragility of a reinforced concrete element to snow avalanches using a non-linear dynamic massspring model, Nat. Hazards Earth Syst. Sci. 18 (9) (2018) 2507-2524, https://doi. org/10.5194/nhess-18-2507-2018.

[35] P. Favier, N. Eckert, D. Bertrand, M. Naaim, Sensitivity of avalanche risk to vulnerability relations, Cold Reg. Sci. Technol. 108 (2014) 163-177, https://doi. org/10.1016/j.coldregions.2014.08.009.

[36] P. Favier, N. Eckert, T. Faug, D. Bertrand, M. Naaim, Avalanche risk evaluation and protective dam optimal design using extreme value statistics, J. Glaciol. 62 (234) (2016) 725-749, https://doi.org/10.1017/jog.2016.64.

[37] A. Favillier, S. Guillet, D. Trappmann, P. Morel, J. Lopez-Saez, N. Eckert, G. Zenhäusern, J.-L. Peiry, M. Stoffel, C. Corona, Spatio-temporal maps of past avalanche events derived from tree-ring analysis: a case study in the Zermatt valley (Valais, Switzerland), Cold Reg. Sci. Technol. 154 (2018) 9-22, https://doi.org/ 10.1016/j.coldregions.2018.06.004.
[38] R. Fell, J. Corominas, C. Bonnard, L. Cascini, E. Leroi, W.Z. Savage, Guidelines for landslide susceptibility, hazard and risk zoning for land use planning, Eng. Geol. 102 (3-4) (2008) 85-98, https://doi.org/10.1016/j.enggeo.2008.03.022.

[39] Robin Fell, Lacasse Ho, Leroi, A framework for landslide risk assessment and management, in: O. Hungr, F. Robin, C. Rejean, E. Erik (Eds.), Landslide Risk Management: Proceedings of the International Conference on Landslide Risk Management, Vancouver, Canada, 31 May - 3 June 2005, taylor \& francis group edition, Balkema, London, 2005, pp. 3-26. OCLC: 255752910.

[40] F. Ferrari, A. Giacomini, K. Thoeni, Qualitative rockfall hazard assessment: a comprehensive review of current practices, Rock Mech. Rock Eng. 49 (7) (2016) 2865-2922, https://doi.org/10.1007/s00603-016-0918-z.

[41] M. Guerra, M. Centeno, Are quantile risk measures suitable for risk-transfer decisions? Insur. Math. Econ. 50 (3) (2012) 446-461, https://doi.org/10.1016/j insmatheco.2012.02.006.

[42] F. Guzzetti, P. Reichenbach, S. Ghigi, Rockfall hazard and risk assessment along a transportation corridor in the nera valley, central Italy, Environ. Manag. 34 (2) (2004) 191-208, https://doi.org/10.1007/s00267-003-0021-6.

[43] D. Hantz, Quantitative assessment of diffuse rock fall hazard along a cliff foot, Nat. Hazards Earth Syst. Sci. 11 (5) (2011) 1303-1309, https://doi.org/10.5194/nhess11-1303-2011.

[44] U. Haque, P. Blum, P.F. da Silva, P. Andersen, J. Pilz, S.R. Chalov, J.-P. Malet, M. J. Auflic, N. Andres, E. Poyiadji, P.C. Lamas, W. Zhang, I. Peshevski, H. G. Pétursson, T. Kurt, N. Dobrev, J.C. Garcia-Davalillo, M. Halkia, S. Ferri, G. Gaprindashvili, J. Engström, D. Keellings, Fatal landslides in europe, Landslides 13 (6) (2016) 1545-1554, https://doi.org/10.1007/s10346-016-0689-3.

[45] O. Hungr, S. Evans, J. Hazzard, Magnitude and frequency of rock falls and rock slides along the main transportation corridors of southwestern british columbia, Can. Geotech. J. 36 (2) (1999) 224-238, https://doi.org/10.1139/cgj-36-2-224.

[46] O. Hungr, S. Leroueil, L. Picarelli, The varnes classification of landslide types, an update, Landslides 11 (2) (2014) 167-194, https://doi.org/10.1007/s10346-0130436-y.

[47] S. Lari, P. Frattini, G. Crosta, A probabilistic approach for landslide hazard analysis, Eng. Geol. 182 (2014) 3-14, https://doi.org/10.1016/j.enggeo.2014.07.015.

[48] J. Lopez-Saez, C. Corona, N. Eckert, M. Stoffel, F. Bourrier, F. Berger, Impacts of land-use and land-cover changes on rockfall propagation: insights from the Grenoble conurbation, Sci. Total Environ. 547 (2016) 345-355, https://doi.org/ 10.1016/j.scitotenv.2015.12.148.

[49] A. Loye, M. Jaboyedoff, A. Pedrazzini, Identification of potential rockfall source areas at a regional scale using a DEM-based geomorphometric analysis, Nat. Hazards Earth Syst. Sci. 9 (5) (2009) 1643-1653, https://doi.org/10.5194/nhess9-1643-2009.

[50] O. Mavrouli, J. Corominas, Rockfall vulnerability assessment for reinforced concrete buildings, Nat. Hazards Earth Syst. Sci. 10 (10) (2010) 2055-2066, https://doi.org/10.5194/nhess-10-2055-2010.

[51] A.J. McNeil, R. Frey, P. Embrechts, Quantitative Risk Management: Concepts, Techniques and Tools. Princeton Series in Finance, revised edition edition, Princeton University Press, Princeton, NJ, 2015. OCLC: ocn894625411.

[52] C. Michoud, M.-H. Derron, P. Horton, M. Jaboyedoff, F.-J. Baillifard, A. Loye, P. Nicolet, A. Pedrazzini, A. Queyrel, Rockfall hazard and risk assessments along roads at a regional scale: example in swiss alps, Nat. Hazards Earth Syst. Sci. 12 (3) (2012) 615-629, https://doi.org/10.5194/nhess-12-615-2012.

[53] S. Mineo, Comparing rockfall hazard and risk assessment procedures along roads for different planning purposes, J. Mt. Sci. 17 (3) (2020) 653-669, https://doi.org/ 10.1007/s11629-019-5766-3.

[54] C. Moos, M. Fehlmann, D. Trappmann, M. Stoffel, L. Dorren, Integrating the mitigating effect of forests into quantitative rockfall risk analysis Two case studies in Switzerland, Int. J. Disaster Risk Reduct. (2017), https://doi.org/10.1016/j. ijdrr.2017.09.036.

[55] J. Noetzli, Mountain Permafrost and Recent Alpine Rock-Fall Events: a Gis-Based Approach to Determine Critical Factors, Balkema Publishers, 2003, https://doi. org/10.5167/uzh-33321. Technical report.

[56] P. Peduzzi, The disaster risk, global change, and sustainability nexus, Sustainability 11 (4) (2019) 957.

[57] J. Pickands, Statistical inference using extreme order statistics, Ann. Stat. 3 (1) (1975) 119-131, https://doi.org/10.1214/aos/1176343003.

[58] O. Pörtner, D. Roberts, V. Masson-Delmotte, P. Zhai, M. Tignor, E. Poloczanska, K. Mintenbeck, M. Nicolai, A. Okem, J. Petzold, B. Rama, N. Weyer (Eds.), IPCC Special Report on the Ocean and Cryosphere in a Changing Climate, 2019.

[59] O. Renn, Concepts of risk: an interdisciplinary review-part 2: integrative approaches, GAIA-Ecol. Perspect. Sci. Soc. 17 (2) (2008) 196-204.

[60] O. Renn, Concepts of risk: an interdisciplinary review part 1: disciplinary risk concepts, GAIA-Ecol. Perspect. Sci. Soc. 17 (1) (2008) 50-66.

[61] C. Scavia, M. Barbero, M. Castelli, M. Marchelli, D. Peila, G. Torsello, G. Vallero, Evaluating rockfall risk: some critical aspects, Geosciences 10 (3) (2020) 98, https://doi.org/10.3390/geosciences10030098.

[62] D. Straub, M. Schubert, Modeling and managing uncertainties in rock-fall hazards, Georisk 2 (1) (2008) 1-15, https://doi.org/10.1080/17499510701835696.

[63] D. Toe, F. Bourrier, L. Dorren, F. Berger, A novel dem approach to simulate block propagation on forested slopes, Rock Mech. Rock Eng. 51 (3) (2018) 811-825, https://doi.org/10.1007/s00603-017-1348-2.

[64] United Nations International Strategy for Disaster Reduction, Global Assessment Report on Disaster Risk Reduction 2019, Global Assessment Report on Disaster Risk Reduction (GAR), UN, 2019, https://doi.org/10.18356/f4ae4888-en.

[65] D.J. Varnes, Landslide Hazard Zonation: a Review of Principles and Practice, Unesco, Paris, 1984. Number 3 in Natural hazards. 
[66] X. Wang, P. Frattini, D. Stead, J. Sun, H. Liu, A. Valagussa, L. Li, Dynamic rockfall risk analysis, Eng. Geol. 272 (2020) 105622, https://doi.org/10.1016/j. enggeo.2020.105622.

[67] Y. Xu, Y.-K. Tung, J. Li, S. Niu, Alternative risk measure for decision-making under uncertainty in water management, Prog. Nat. Sci. 19 (1) (2009) 115-119, https: / doi.org/10.1016/j.pnsc.2008.07.005.
[68] H. Yoshikawa, K. Goda, Financial seismic risk analysis of building portfolios, Nat. Hazards Rev. 15 (2) (2014) 112-120, https://doi.org/10.1061/(ASCE)NH.15276996.0000129.

[69] K. Zheng, L.A. Albert, A robust approach for mitigating risks in cyber supply chains: a robust approach for mitigating risks in cyber supply chains, Risk Anal. (2019), https://doi.org/10.1111/risa.13269. 